iF 197

S3

opy 1

\title{
SPECIAL CONTRIBUTOR
}

PROF. THOMAS SHAW

\section{Published by \\ THE S. R. FEIL CO., M'f'g. Chemists, CLEVELAND, OHIO}



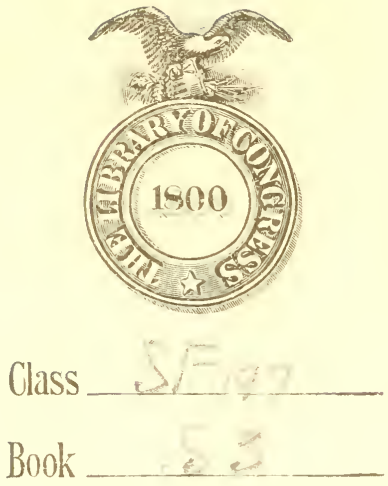

Copyrighlt $\mathrm{N}^{0}$.

COPYRIGHT DEPOSIT. 



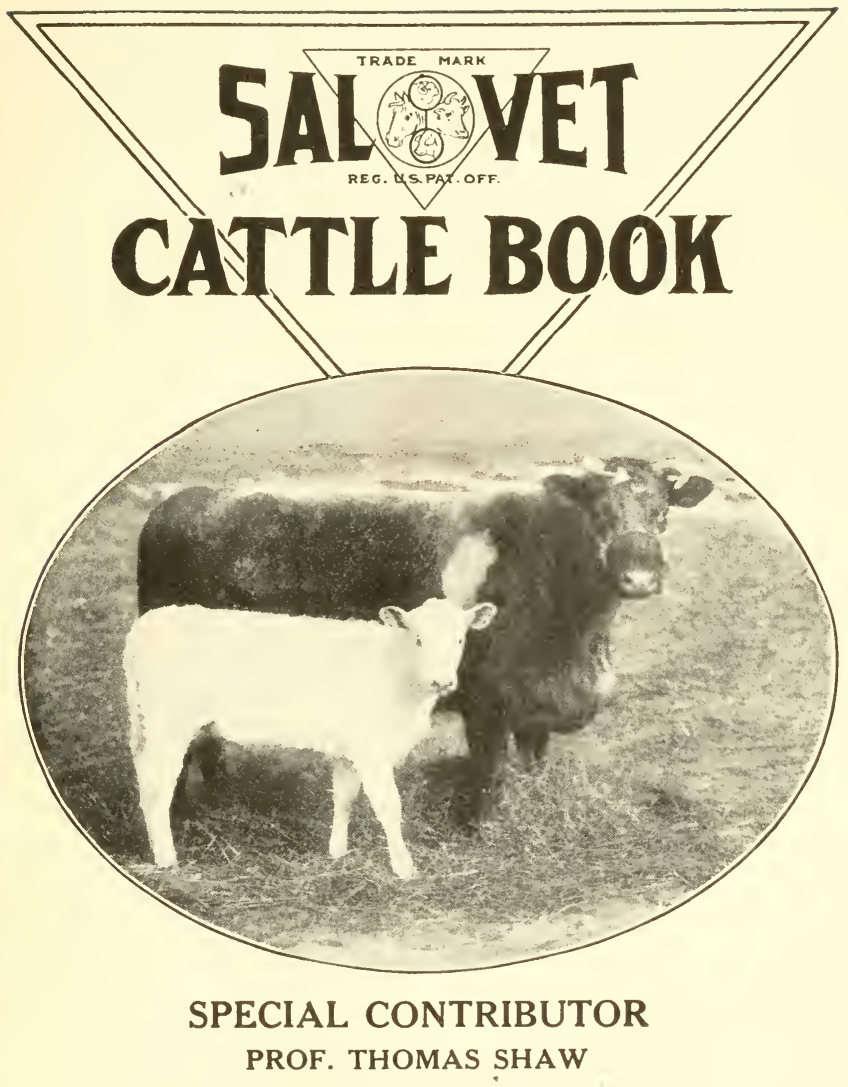

Published by

THE S. R. FEIL CO., Mfg. Chemists

CLEVELAND, OHIO. 


\section{The}

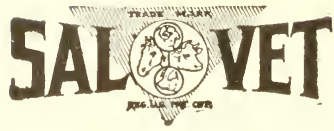

\section{Stockmen's Library.}

Cattle Book, Illustrated Price $50 \mathrm{cts}$.

Sheep Book, Illustrated Price 50 cts.

Swine Book, Illustrated Price 50 cts.

Horse Book, Illustrated Price 50 cts.

Each of these books has a valuable colored anatomical chart, as a supplement.

Copyright, 1913,

By THE S. R. FEIL CO.,

Cleveland, $\mathrm{O}$.

(C) Cl. A:47:3: 


\section{PREFACE}

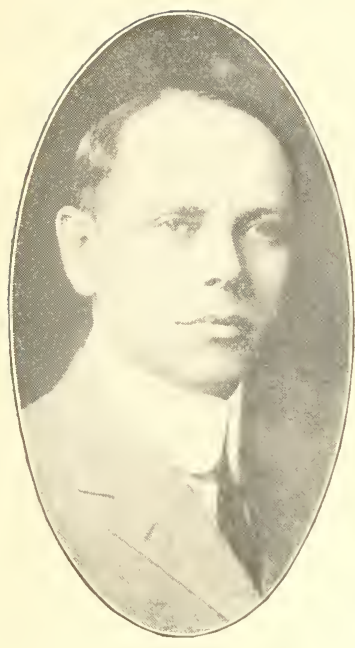

The success or failure of every stock farmer, dairyman or beef breeder, depends upon his selection of stock, and the kind of care and management he gives his animals. In this book we have attempted to set forth in a brief manner, the information most essential to success. We have not attempted to present any new theories, but rather to present the old, tried and proved methods, in a clear and practical manner, so that the most inexperienced can understand and follow them. If you find portions of this book very elementary, please remember it is because we have tried to avoid technical instruction, and to present the subject in such a way that an inexperienced boy can fully understand In treating disease we have recommended generous use of "Sal-Vet" because we know from our own experience and the experience of the well-informed farmers, stock raisers, and experiment stations, that "Sal-Vet" is the greatest known preventive of certain ills which result in stock losses.

Our sole desire in compiling this book is that it may be the means of increasing the profits of the stock farmer, dairyman and breeder. If the reader is able to find in these pages a few hints and helps that will assist him along the road to success, we shall feel amply rewarded for our time and trouble. Sidney R. FeIL, Pres.,

The S. R. Feil Co., Cleveland, Ohio. 


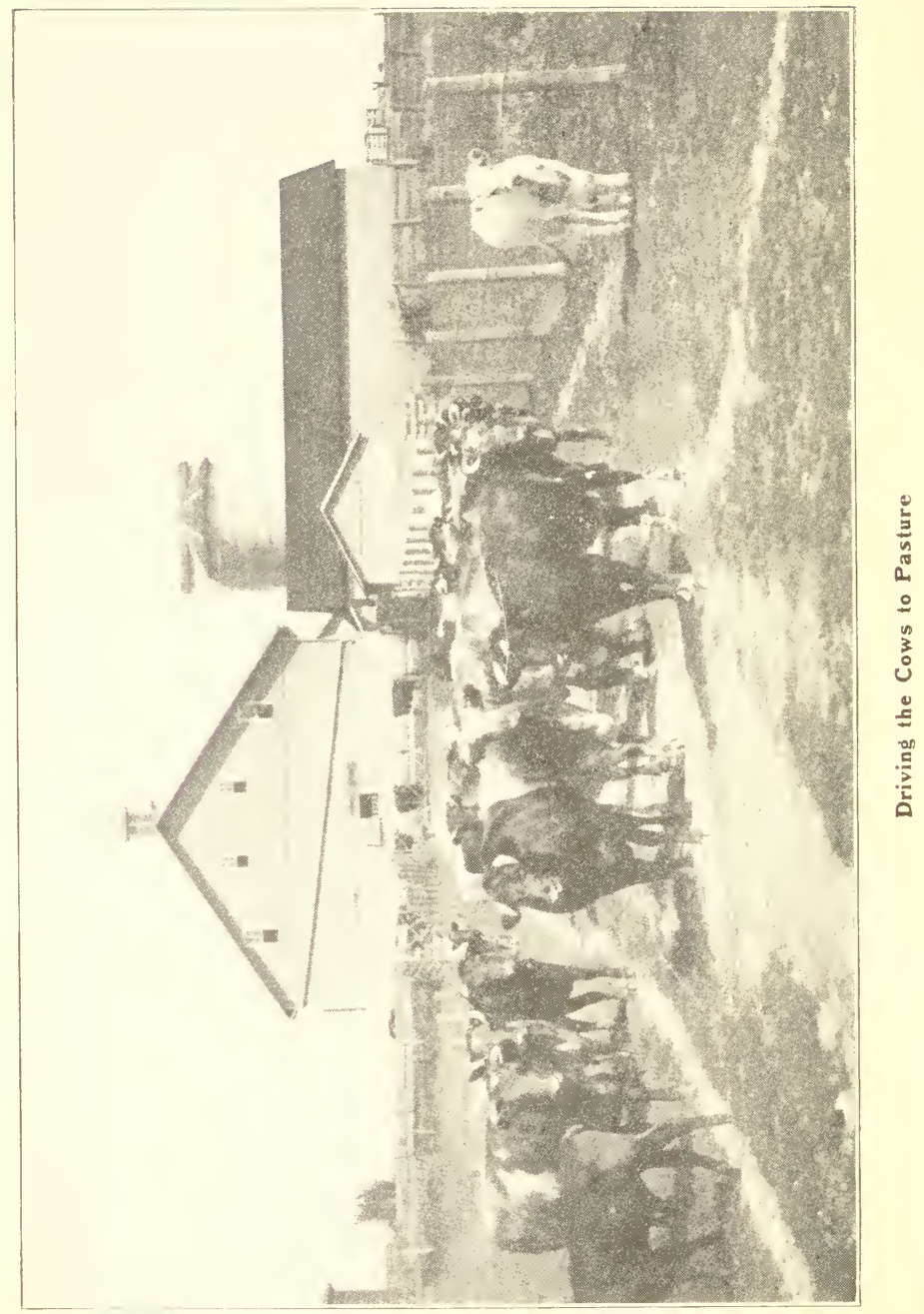




\section{Cattle}

Their Breeding, Feeding and Management.

(Pages 5 to 56 Inclusive)

By PROF. THOS. SHAW.

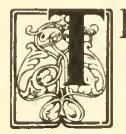

$\mathrm{HE}$ cattle industry will always dominate among the live stock industries of the United States. This follows from the necessity that will always exist for furnishing meat and milk, for the use of the rapidly increasing millions that will populate this country. No other class of

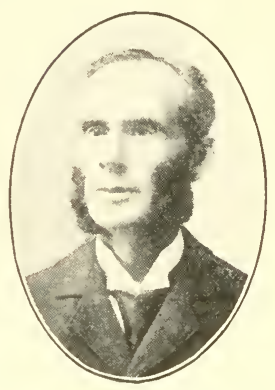

Prof. Thos. Shaw live stock can serve this combined purpose as it is served by cattle. The importance, therefore, of knowing how to breed, feed and manage this class of stock in the best way, cannot be easily over-estimated.

\section{Breeding Cattle.}

Cattle are of three classes in the United States, viz. those kept mainly or exclusively for furnishing beef, those kept mainly or exclusively for furnishing milk, and those kept for the combined purpose of furnishing meat and milk. Cattle of the first class should be grown chiefly on range and rug- 
ged pastures, but when high class baby beef is wanted, they may be kept on the arable farm. Cattle of the second class are grown and maintained on the arable farm, and the same is true of dual purpose cattle, that is of cattle of the third class. Milk for the dairy should not be sought from those of the first class. Meat should not be sought from those of the second class while yet profitable in the dairy, except from calves that are vealed, or from progeny sired by a male of the first class, when the calves are not to be reared for dairy uses. Much of the meat grown on the arable farm should come from cattle of the third class and also much of the milk that is wanted for sale, or for the manufacturing of dairy products.

\section{Principles that Govern in Breeding:-The} principles which govern the breeding of these three classes of cattle are essentially the same. They have regard- (1) to pedigree, (2) to form, and (3) to selection. Pedigree recognizes the fact that the more purely bred the animals are and the longer the period that they have been so bred, the more certain will be the transmission. Because of this, pure bred males only should 
BREEDING, FEEDING AND MANAGEMENT

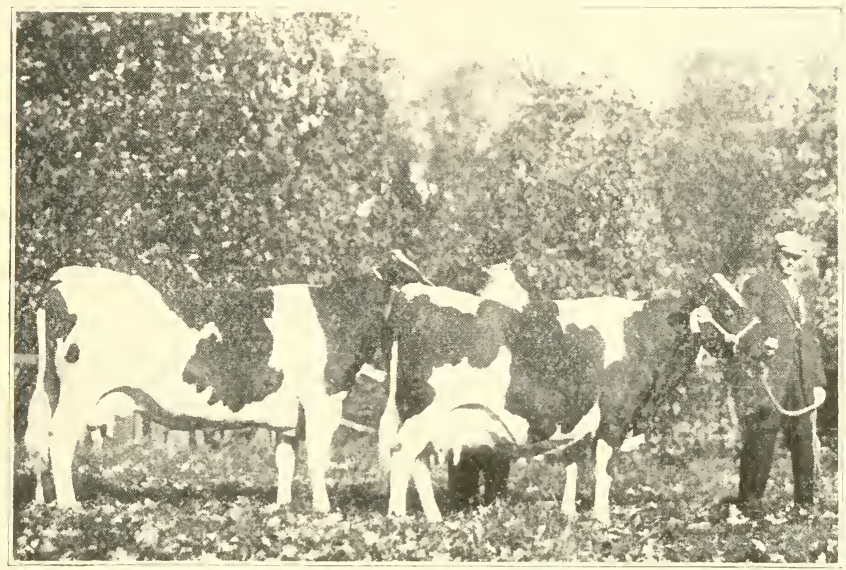

Typical Dairy Cows

be used, whatsoever the character of the females may be. The form should approximate as closely as possible to that recognized as the standard for each particular class. Selection should reject for breeding all animals that do not approximate closely to the standard form.

\section{Breeding Pure Breds:-Pure breds can} only be bred from sire and dam of the same breed when both are registered, or are eligible to registry. Both sire and dam should possess good form, and if possible, both should come from ancestry that in the near- 
est generations have shown high excellence in meeting the requirements for which they are kept. This is especially important in regard to the male, because of the influence which he exerts on so many of the progeny. When a good male has shown himself to be prepotent, he should be kept in the herd as long as he is useful in the same. Prepotency means the ability to stamp on the progeny individual characteristics. Marked prepotency is rare rather than frequent. Those who breed pure breds, should be possessed of business tact as well as of skill in breeding, if they are to succeed.

Breeding Grades:-The great mass of the live stock kept upon the farms of this country, through all time, will be grades, because of the greater skill called for and expense entailed when breeding pure breds, hence the great importance of knowing how to do this in best form. When breeding grades, the blood elements of the females is not unimportant, but blood much mixed is no objection, if the form is reasonably good. In fact, the more mixed the blood in the female, the greater relatively will be the improvement from using a pure bred sire. Good individuals only of the progeny should be 
saved for future breeding. The successive males used, should all come from the same breed. I say four generations of such breeding for beef animals, and five for milk, the animals resulting should be as good individually as the average of the breed from which the sires have been chosen. They may be even more rugged because of the blending of alien blood element. 'This will follow though the foundation females have been very common in kind. This kind of breeding is frequently spoken of as up-grading. If any change of breed is made when choosing sires, transmission pertaining to the line of grading previously followed, will be proportionately weakened, and the more frequently that such change is made, the more uncertain will the result be.

Breeding Cross Breds:- When animals of the pure breeds are mated, or even when very high grades of these are mated, the progeny are known as crossbreds. It is seldom advisable to breed pure breds thus. For breeding uses, they are usually more valuable than even the progeny becomes, and there is more or less of a tendency to deterioration in succeeding generations. 


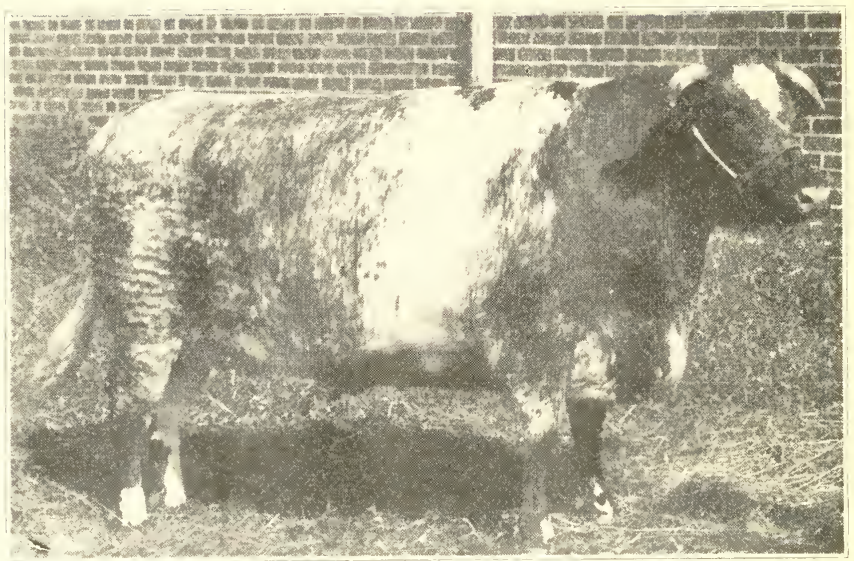

"Of Compact Build and Short in Limb"

Selecting Beef Cattle:-When selecting cattle for beef, the animals chosen should have the following characteristics of form:

(1) They should be of compact build and short in limb.

(2) The back should be level, broad in all parts and well covered with soft flesh when the animal is in condition.

(3) The fore-quarter should be wide, full and deep.

(4) The hind quarter should be long and broad, and should come well down in flank and twist. 


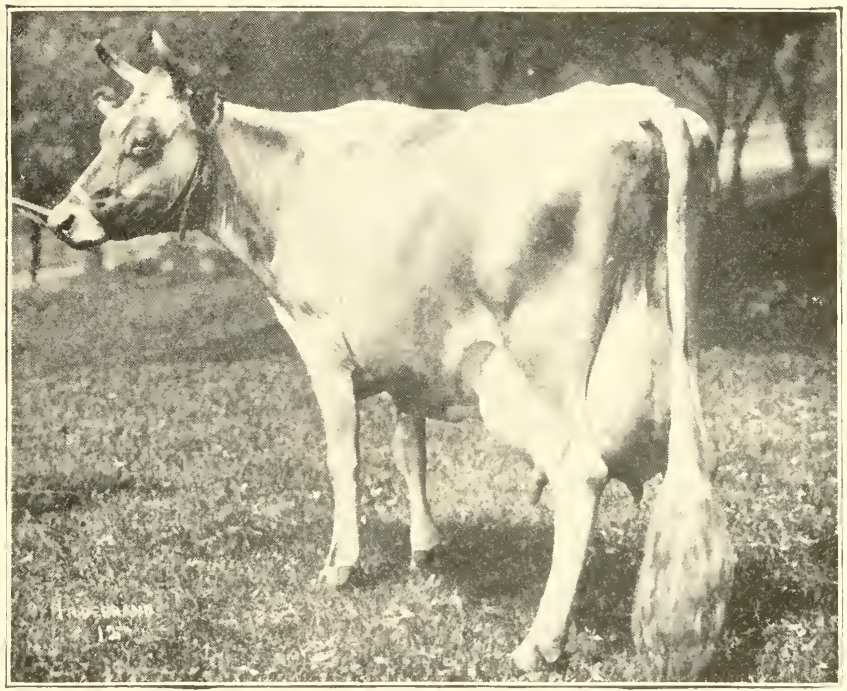

Evidences of Good Milking Capacity

(5) The hide should be soft and readily moveable, especially over the ribs.

(6) The head and neck should incline to short, the eye being calm, and the entire body should be smooth and free from prominences.

Selecting Dairy Cattle:-When selecting cattle for the dairy, the aim should be to 
choose animals with the following characteristics:

(1) Much capacity in the barrel to provide large storage for the food consumed.

(2) A general outline more or less required, as seen in a head and neck, inclining to fine sharp withers, a well defined spinal column, light thighs and limbs fine, rather than coarse.

(3) Evidences of good milking capacity as shown in a large and evenly quartered udder coming well up behind and glandular or spongy in its quality when empty, also in long and tortuous milk veins going into the body, through large openings.

(4) Considerable width through the lower part of the chest, as a guaranty of ruggedness.

(5) A nice handling, pliable skin.

Selecting Cattle of the Dual Types:-When selecting cattle of the dual type, look for the following:

(1) Development that is something of a mean between extreme beef and extreme dairy form.

(2) Good capacity of body with ribs a little open space, rather than close.

(3) A head and neck inclining to fine; 
withers medium, back level and medium wide, and hips straight on the side and rear, rather than incurved.

(4) Good large development of udder and milk veins.

(5) A pliable skin of medium thickness and covered with soft hair. With all these classes of cattle, those of large size for the breed or grade are to be preferred.

The Breeds of Cattle:-The beef breeds of cattle in America at the present time are the Shorthorn, the Hereford, the Aberdeen Angus, and the Galloway, The Shorthorns are the largest of these breeds, and they are well adapted to stall feeding. The Herefords are excellent grazers. The Aberdeen Angus furnish high quality meat. The Galloways are well adapted to roughing it in cold climates, and their hides make fine robes. The high grades of these are possessed of similar characteristics. The dairy breeds are the Holsteins, the Ayrshire, the Guernsey and the Jersey. The Holsteins are a large breed, and they are specially noted for the large amount of milk which they give, but it contains less butter fat than the milk of the other breeds named. The Ayrshires breed furnish milk well adapted to making cheese or butter. The Guernseys and the Jerseys give only a medium quantity of milk but it is exceeding rich in butter fat. The Dutch Belted Cattle with a white band or belt around the body are much like the Holstein in other respects. They are not numerous in this country, and the same is true of the other dairy breeds, the Kerry and the French Canadian.

The dual breeds are the Brown Swiss, the milking Shorthorn and the Red Poll, The Brown Swiss are frequently classed as a dairy breed. The great bulk of the dual types of cattle are found among grades, rather than among the pure breeds. 


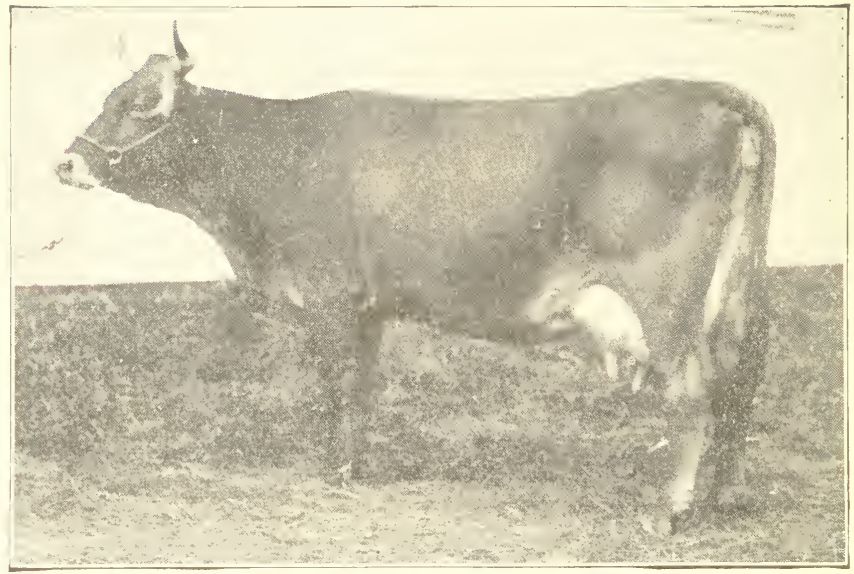

A Prize Winning Brown Swiss Cow

\section{DUAL BREEDS}

\section{Brown Swiss}

The Brown Swiss, as their name indicates, are natives of Switzerland. Bred in a rugged, mountainous environment, they are extremely hardy and adapted to rough pasturing. They are coarse of build, yet give a good flow of milk with a fair percentage of butter fat. This combination of beef and dairy types, makes them popular among that class of breeders who desire a general utility animal. They are of generous build, of dark brown to chestnut brown color. Horns are short and waxy with black tip, black nose and tongue, white thighs. The cows at maturity often weigh 1600 pounds and the bulls 2000 pounds. 


\section{DUAL BREEDS}

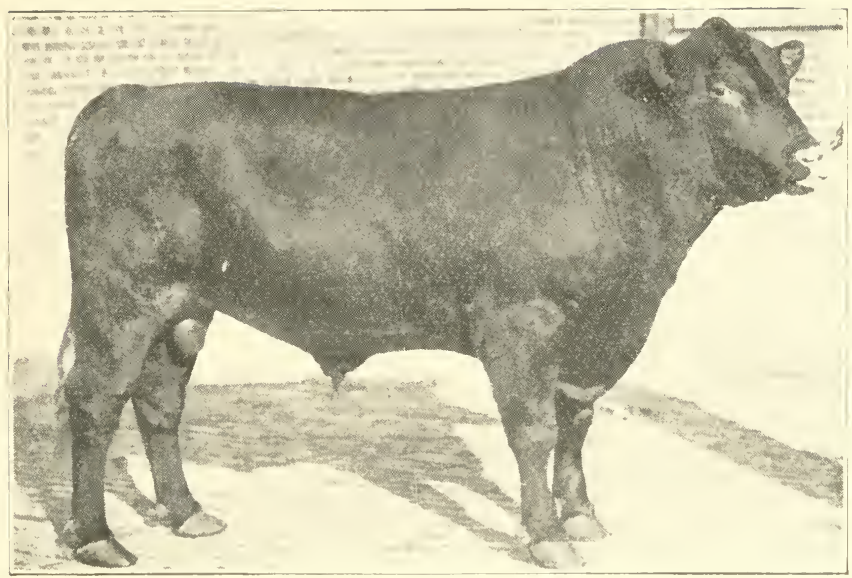

A Champion Red Poll Bull

\section{Red Polls}

The Red Poll cattle are of English origin. The present type is a combination of the Norfolk and Suffolk Polled. They are hardy and well adapted to severe cold and exposure; for this reason they are finding increasing favor in the northern and western states. They are of medium size, compactiy built and give a good flow of milk, fairly rich. Forty to fifty pounds per day is a fair average. A good Red Poll cow will easily give 6,000 pounds of $t$ percent milk a year. 'They are well developed in beefing qualitics, being especinlly well covered in parts which produce the hise t guality meat. 


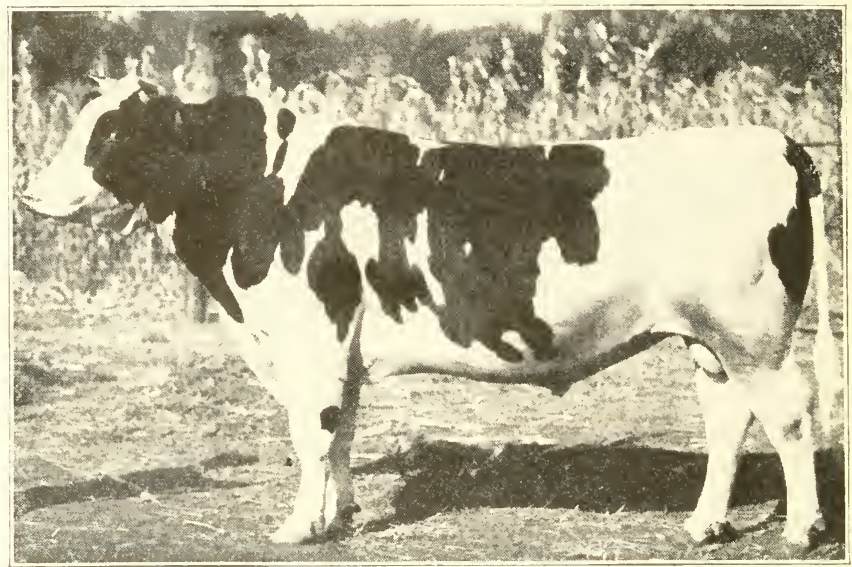

A Fine Specimen of Holstein Bull

\section{DAIRY BREEDS}

\section{Holsteins}

The Holstein-Friesians are extreme milk producers. The milking capacity of the Holstein is estimated to be three times that of smaller cows. They are profitable dairy cows, essentially healthy and easily handled. Holstein cows have taken worlds' records for milk, butter and chcese. As their name indicates, they are of German or Dutch origin. The name is a compromise, inasmuch as the breed is a union of several different families. The build and size is very nearly uniform. The most noted feature of the body, is the large rounded barrel indicating digestive capacity. Udders are very large and extend well forward. 'The color is white and black.

l'age sixtern 


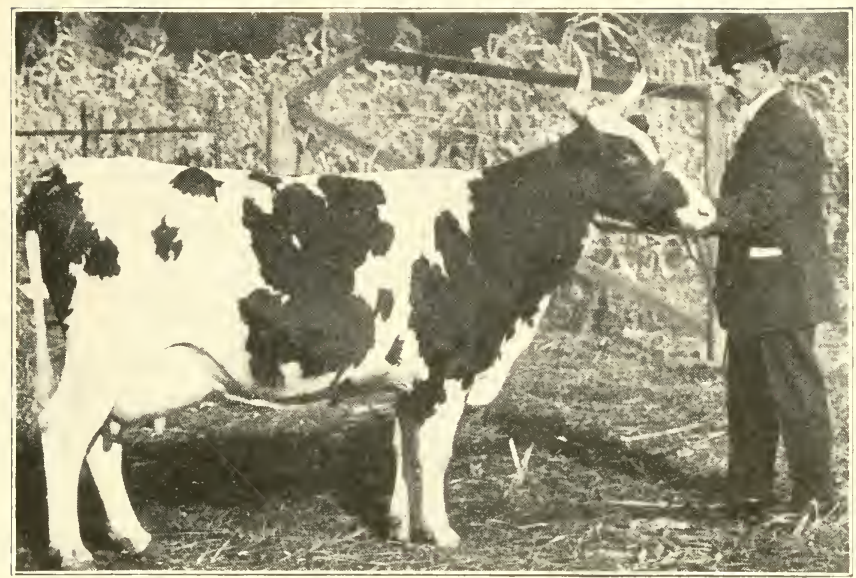

"Gentle in Disposition But Always Alert"

\section{Ayrshire}

The Ayrshire is a native of Scotland, county of Ayr. The rugged conditions under which the breed was developed, produced a type calculated to make the best possible use of their feed, and thrive under the severe exposure. Many admirers say they will produce more milk for the amount of food consumed, than any other breed. Their milk is said to be perfect food for infants and invalids. They are gentle in disposition yet noticeably alert. The skin is soft and loose and covered with thick, soft, woolly hair. Color is red, brown or white or a combination of these. 


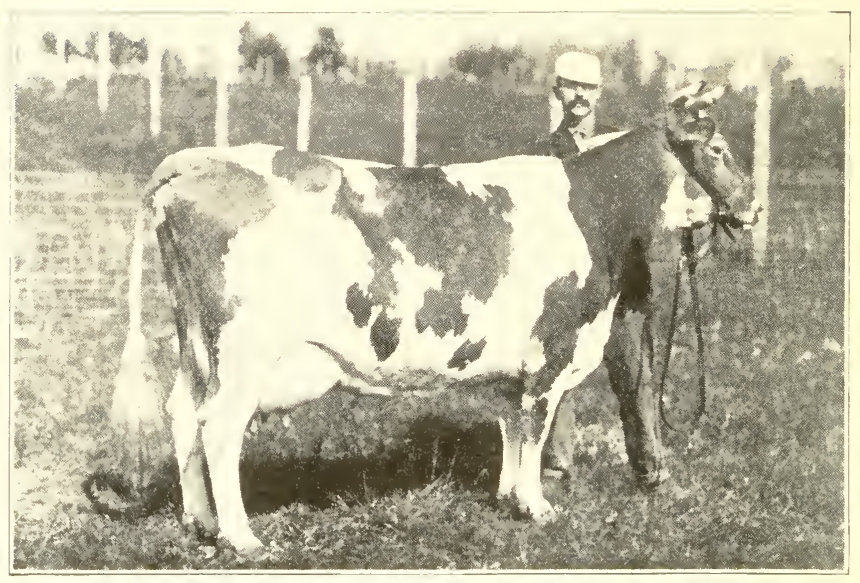

\section{A Prize Winning Guernsey Cow Guernsey}

The origin of the Guernsey cattle was on the Island of Guernsey, one of the channel group. The Guernsey is one of the most popular breeds, because of its heavy yield of milk and its richness in butter fat. The chief characteristic of the Guernsey is her economical production of the highest natural-colored milk, cream and butter. While no attention has been given to markings, their long protection has developed a distinct type. The coat is usually fawn with white markings, overlaying a skin of rich orange. They have clean cut, lean faces, wide nostrils and bright eyes with a gentle, quiet expression. The abdomen is large and deep, showing great digestive and productive capacity. Udder is of large size and capacity. The teats are of good size and well placed. Average weight of mature cow 900 to 1000 pounds. 


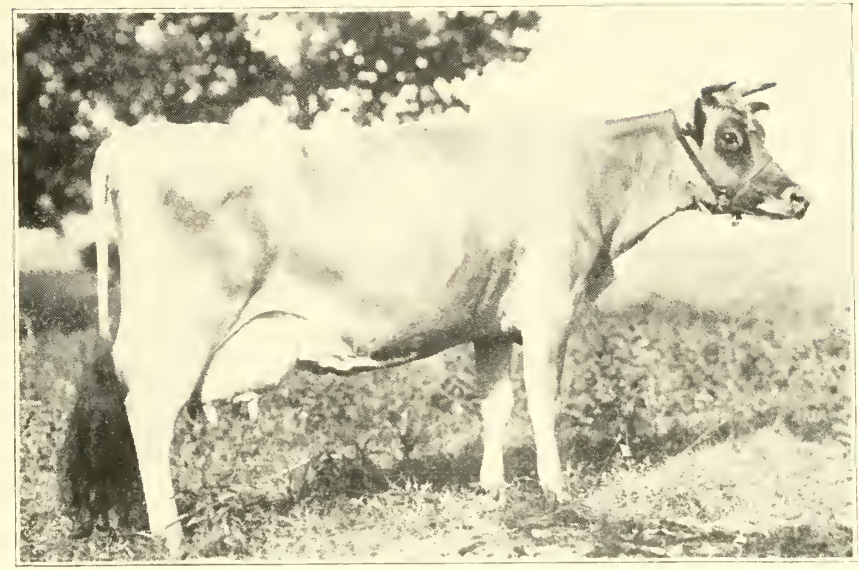

A Typical Pure Bred Jersey Cow

\section{Jersey}

The native home of the Jersey cattle is the Island of Jersey, one of the Channel islands off the coast of France. No breed stands higher in the favor of American dairyman. They give the most milk for their size and weight, and produce a pound of butter fat or a pound of milk solids, at the least cost in feed. Dairy products made from Jersey milk are unsurpassed in quality and flavor. Their milk is very rich and especially adapted to butter making. They are a beautiful type of dairy cow, distinguished by their deer like heads, deep narrow fore-quarters, large bodies and fawn color. Mildness and gentleness characterize the disposition of this breed. 


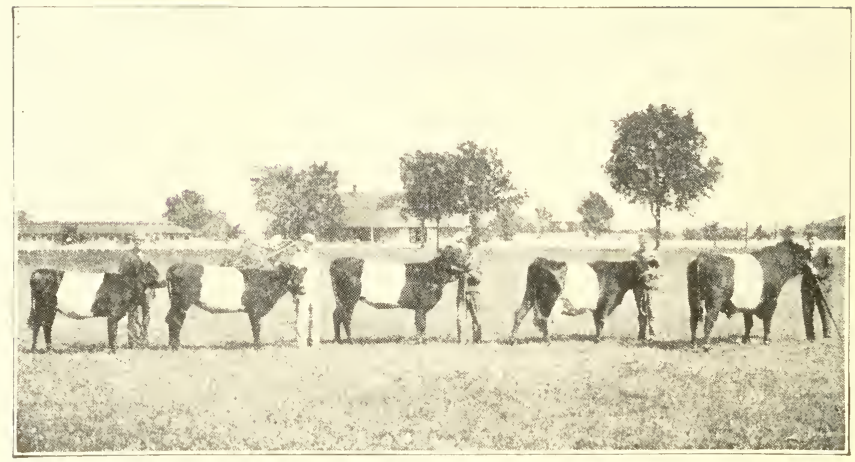

A Pretty Group of the Dutch Belted Breed

\section{Dutch Belted}

The Dutch Bclted cattle are a Holland breed and are designated as "belted" because of the wide, white band which encircles the body. With the exception of this encircling band of white, the cattle are black. They are strictly a dairy breed, being heavy milk producers. The cows range from 800 to 1200 pounds in weight, while the bulls range from 1800 to 2200 pounds. The characteristics of the Dutch Belted cattle are, long head, broad between the eyes, horns long in proportion to their size, fine thin neck, short legs, wide hips, white band around body, large well developed udder, quiet disposition. They are bred only to a limited extent in this country. 


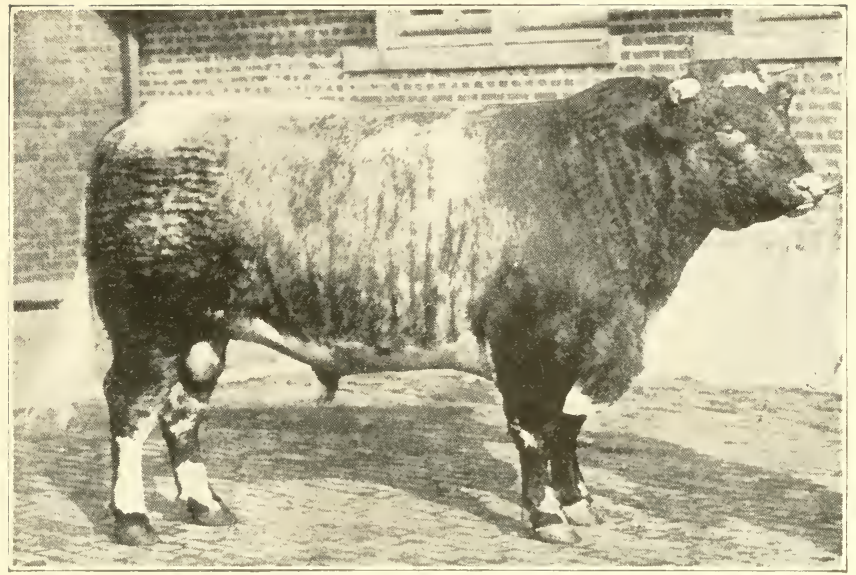

A Champion Short Horn Bull Shorthorn

The Shorthorn was imported into the United States from England and Scotland. They were formerly called Durhams and are unexcelled as a beef breed. The Shorthorn is a development of three types; the Bates, the Booths, and the Cruickshanks. The characteristics of the Bates are clean lines, finely shaped heads and broad level backs. The Booth characteristics are shown by the girth, lengthy quarters and deep flesh. The C.ruickshanks carried low, broad and deep forms and were stock of quick maturity. The modern Shorthorn is a combination of all these characteristics, which make them the favorite among beef producers, but they have also been bred up to a good milk producing standard. The predominating colors are red, white and roan. 


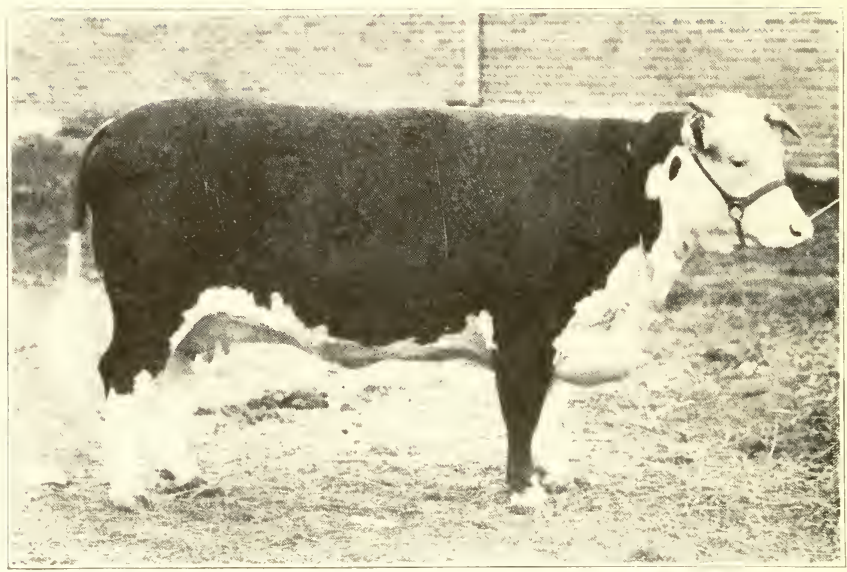

\section{A Champion Hereford Cow}

\section{Herefords}

The Herefords are so called from their point of origin, Herefordshire, England. 'They are superior for beef purposes and are also good, but not deep milkers. They are better producers of cheese than of butter. The cows average about 1300 pounds in weight. They are a picturesque breed with their white faces, chest, legs, under body, end of tail and strip on top of neck. The rest of the body is red. They are low set and broad with heavy forequarters, deep chest and level, wide back. Herefords are characteristically thrifty and good grazers. In the best specimens of the breed the coat is thick and mossy, which is indicative of thrift. 


\section{BEEF BREEDS}

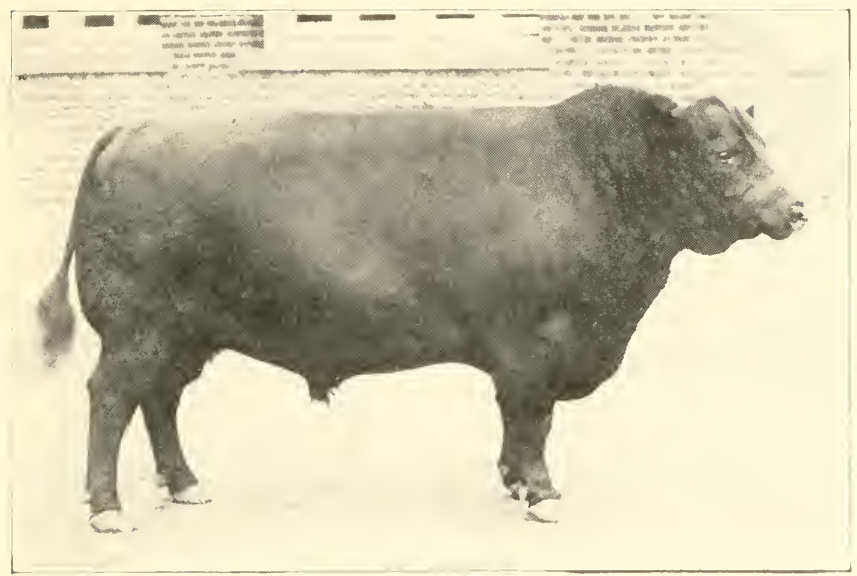

A Prize Winning Angus

\section{Aberdeen Angus}

The Aberdeen Angus is a native of Scotland,-a hardy, black, hornless breed. While not so large as some beef breeds, they are profitable keepers. Their frames are covered smoothly and evenly at all points with deep mellow flesh. The type is favorable to the production of the highest quality beef in the greatest quantity. Their hide is pliable and covered with fine black hair, and properly tanned, makes excellent carriage robes. The Angus has strong shoulders, deep circular ribs; hips moderately far apart and well covered. 


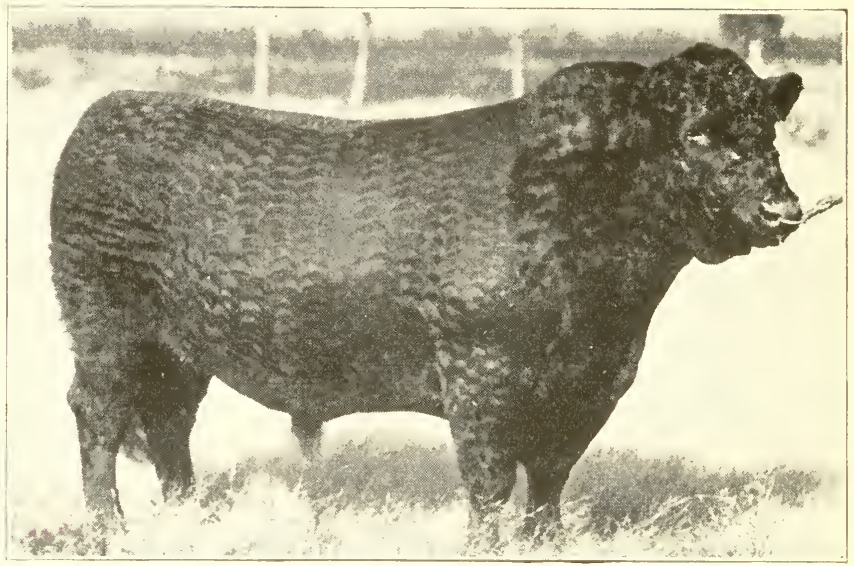

A Champion Galloway Bull

\section{Galloway}

The Galloway breed derives its name from its native district in Scotland. Their coat is black with a tinge of brown. They are especially adapted to cold climates and exposed countries. Galloway hides are covered with a soft, wavy, thick coat of hair, with a mossy undercoat, and are exceedingly valuable for heavy coats and robes. They are smaller than some of the beef breeds and do not mature as early, but are being rapidly improved. The type is thick, symmetrical, built close to the ground and have short wide heads, without horns. 


\section{Devon}

The Devon is of English origin. They are not so heavy as the Shorthorns and Herefords, but are larger than the Ayrshires, Jerseys, or Holsteins. The milk is said to be particularly good food, especially adapted to infants. Under proper management Devon cows produce 15 to 25 pounds of butter per week. The flesh is greatly prized for its high quality. The characteristics of the Devon are a moderately long head with broad forehead, ears thin, long graceful upturned horns, medium length neck, straight level back, hind quarters deep, thick and square. Color, red.

\section{Feeding Cattle.}

Fundamental Principles:-There are certain fundamental principles which obtain in the successful feeding and raising of cattle, which cannot be ignored. These relate:

(1) to the source from which the foods are obtained;

(2) to the character of the foods fed, and

(3) to the manner of feeding them. 
The source of foods:- ()$_{n}$ the arable farm the grower of live stock should aim to grow all the food that he needs on his own farm. This should be his aim, first, because he can usually grow it more cheaply on the arable farm than he can buy it; second, because he can grow it in combinations that are desired; and third, secause he may thus command the quality of the source. But there may be instances where buying a part of the food is not only desirable, but commendable, especially when bought in the form of grain, to supplement what is grown. The cost of transporting roughage usually places it beyond the reach of the farmer, who must obtain food by purchase.

Adaptation in foods:-Adaptation in the foods fed is of great moment. Certain foods have highest adaptation, for being fed to cattle at certain ages. During the period of calfhood, the animals should be fed roughage, fine in character and of high quality. Between that period and the usual time for fattening, they would be suitable for calves or cows in milk. During the fattening period, it will usually pay well to feed grain, except in some instances, when the animals 
are being grazed on plentiful supplies of succulent grass. When cows are in milk, they must be supplied with more or less of succulent food, if maximum production is to be insured.

Quality in Foods:-The quality in the foods fed is greatly important. In fodders, coarseness and woodiness are undesirable. Overcuring detracts much from their palatability. Sour fodders, as corn and the sorghums, deteriorate quickly with age. To insure the highest palatability in fodders, they should be cut at an early stage of maturity, and cured so that much of the natural color is maintained. Grains also differ much in quality. They are usually superior as the weight increases. Grains that are musty or mouldy should not be fed to cattle.

Feeding Foods in Balance:-The foods fed should be in balance, which means that the protein foods should bear a certain proportion to the carbo-hydrate foods. The relative proportions in these will vary with advance in age, and with the end sought in feeding the food, as when feeding for beef or for milk. Protein foods produce flesh, growth and milk, to a much greater extent 
than they produce fat and heat, hence they should be fed in largest quantity to animals that are growing or furnishing milk. Carbohydrate foods should be thus fed to animals that are being fattened, or that are much exposed to cold. Skim milk and all leguminous plants are rich in protein. Corn, the sorghums and timothy are rich in carbohydrates. In proportion as these foods are fed not in balance, that is, not in due proportion, there will be waste in feeding them. The proportions of each to feed may be ascertained, at least approximately, from tables that may be found in books and bulletins in feeding.

There should be a due relation also between the proportions of the roughage and the bulky products fed. In young animals this is necessary to secure proper distension in the digestive organs; until the fattening or the milk producing period has been reached, the proportionate amount of the roughage may continually increase. In some instances, roughage only may be needed between the milk period with calves, and the period when fattening or milk giving begins. In such instances the roughage should be of high 
quality. With animals that are fattened or producing milk, the larger the proportion of the roughage fed that will secure a given end, the less costly will be the ration, as roughage is usually cheaper than grains. But a certain amount of grain should be fed in such instances to insure maximum results, as the animals can not consume enough of roughage in these instances, except when they are being grazed on pastures rich, abundant, and more or less succulent.

\section{Growth without Cessation:-It is highly} important that animals should be kept growing with reasonable haste, until they are matured. There should be no stand still periods in development short of maturity. Should development beseriously arrested, the capacity for future development is lowered. The earlier the period at which such development is arrested, the more completely that it is arrested, the less complete will be the subsequent development. If, therefore, development is seriously arrested in calfhood, the animal will never develop subsequently as it would have developed, had such a period of arrested growth not come to it.

The cost of development is also thereby 
increased, because of the longer period called for, in which to reach maturity. The food of maintenance of course varies with the age of the animal, but in growing cattle, it is approximately 50 per cent. It is very evident, therefore, that the cost of producing an animal, will increase with increase in the time called for in reaching maturity. It is also apparent that during periods of partial or complete stagnation, the food of maintenance is all lost for the time being. Should the animal lose in weight, the loss will be further increased, and in proportion to the amount of the flesh that has been lost. The mistake so frequently made of allowing growing animals to lose weight in the winter season, will be apparent from what has been said.

Increase in Gains with Age:-With increase in age, the cost of producing meat from cattle continually increases. This follows from that law of growth, which makes it more rapid, the nearer the birth period is approached. Good feeding will secure not less than 2 pounds of increase per day, during the first year. During the second year, similarly good feeding will not usually produce more than 1, pounds of increase per day. Dur- 
ing the third year, the increase will be not more probably than $1 \frac{1}{4}$ pounds per day. When the animal is matured, no further increase is made in weight, notwithstanding the large consumption of food called for. These results are the outcome, first, of the greater activity of the digestive organs as the birth period is approached, and consequently the more perfect way in which the food eaten is utilized, and second, of the greater tax on the food of maintenance. It is very evident, therefore, that the grower of beef, at least on the arable farm, should aim to quickly grow animals intended for beef, and to market them at an age not exceeding three years. In many instances they are sold between the ages of 18 and 24 months. Such meat is known as baby beef. Where a large area of rough and broken pastures is present, it may be more profitable to allow the animals to attain a greater age before marketing them.

Marketing when Ripe:-When animals are fattened, it is important that they shall be put upon the market when ripe. They are ripe when they cease to make profitable increase. This can readily be determined by 


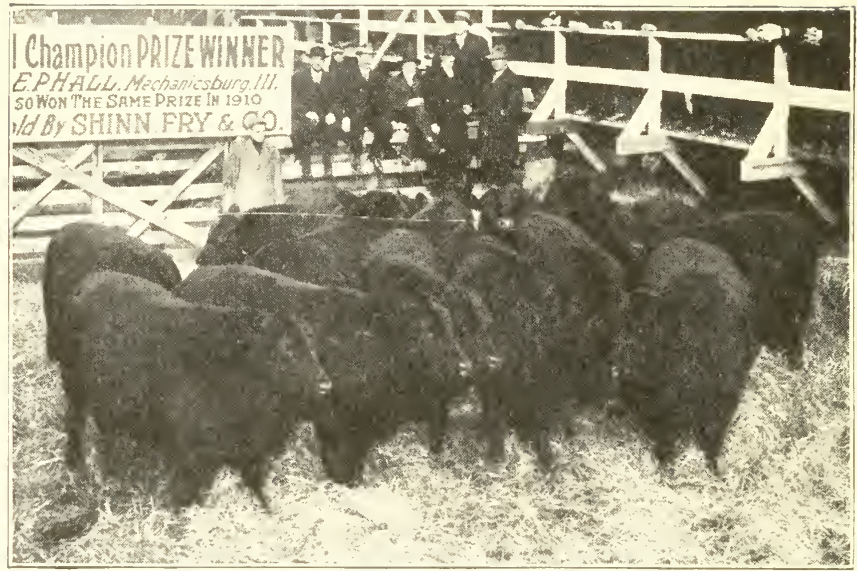

A Bunch of Prize-winning Steers at the Chicago Yards

the weight scale. They are ripe when the covering of flesh is good over all the body and when it becomes firm under pressure of the hand. When this condition has been reached, and the gains in weight have in a great measure ceased, the loss from longer keeping the animal will rapidly accumulate, as it will consume practically as much food, as when at an earlier period, it was making much increase. 


\section{The Management of Cattle}

FE management of cattle includes the following:

(1) The feeding and care of calves.

(2) The feeding and care of young

cattle.

(3) The feeding and care of cattle that are being fattened.

(4) The feeding and care of cows in milk.

These will be discussed separately.

Feeding and Care of Calves. - When rearing calves, the feeding and care are much influenced by the object for which they are reared. In some respects these are the same. In other respects they differ widely.

When Calves Should Come.-Whether calves are to be reared for beef or for the dairy, it is preferable to have them come in the autumn. This is especially true of calves that are reared by hand. When calves are to be vealed, it is not very material when they come.

Calves may come more profitably in the late autumn, for the following reasons:

(1) They may be cared for more completely because of the greater leisure which the farmer has at that season. This will be of special advantage to hand fed calves. 
(2) The time for weaning them is propitious. This will take place in the spring, that is at a season when the grass is becoming plentiful, so that the weaning should give them no setback.

(3) They graze much better the first summer, than do young calves. They are better able to resist the influence of heat and the annoyance from flies, and they can glean and thrive on coarser grass.

(4) They pass through the winter that comes after the weaning, better than spring calves. They are stronger and older and can, therefore, withstand the cold better, and they may also be made to consume a larger proportion of coarser foods than would be suitable for spring calves.

(5) They may be made into baby beef at an opportune age. If marketed in the spring, they may be sold at 18 months. If marketed in the fall, they will be sold at 24 months and with greater advantage, all things considered, than spring calves sold at similar ages.

(6) The cows will be dry at a more opportune season of the year, than if the calves came in the spring. That season is the autumn, when the food is dry. 


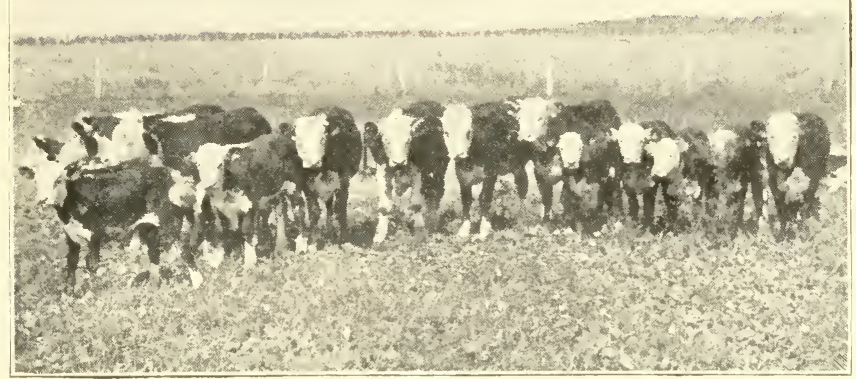

A Fine Group of "Beef" Calves-Herefords

(7) Dairy cows will milk more profitably for the season, first, that they freshen when dairy products are raising in price, and second, that the milk flow is more easily maintained, since the cows are on fresh grass during the latter part of the lactation period.

Calves Reared for Beefs:-Calves for beef are sometimes reared on their dams during the milk period. In some instances they only remain with their dams for two or three days, and then confined and only allowed to take milk from the dam three times a day at a the first, twice later and probably only once 
toward the time of weaning. The latter method is considered the better, as it makes it easily possible to supplement the milk furnished by the dams, and also for other reasons. Usually the calves are weaned at the age of about 6 months. In some instances the first calf is weaned at about four months and a second calf is put upon the dam and allowed to suck for a similar period. One hindrance to the success of this system is found in the difficulty in getting suitable calves.

Calves reared by hand for beef, are frequently of the dual type. They are given skim milk instead of new, save for a short time at first, the cream from the milk produced, being devoted to other uses. When thus reared, they should be allowed to take their first meal from the dam and it will be all the better for them if they can stay with her for a day or two, so that they may take milk at will. The digestion will then be started properly. They may then be taken quite away from the dam. If allowed to go without milk until they are hungry, they may be readily made to take milk from a pail or other vessel.

They should be given new milk for say 
two weeks and fed not seldomer than three times a day, taking care not to give them enough at any one time to derange the digestion. About two quarts should be ample for one feed. At the end of two weeks the change to skim milk may begin. It is made by gradually withholding the new milk and substituting in its place, blood warm skim milk in ever increasing quantities, until only skim milk is given. The process of change should cover about two weeks. Separator skim milk is preferred, chiefly because it may be fed warm and without artificial heating. At the end of a month, two feeds per day should suffice, and it should never be fed to the extent of producing an unduly lax condition of the bowels. The feeding of milk may be closed at the end of 3 or 4 months, but may be continued longer, if desired. Good skim milk will produce nearly as much growth as new milk, but will furnish fat making material. To insure a good condition of flesh, some oil meal or ground linseed should be added to the milk, beginning with a small tablespoonful at first or even less, and increasing as the calves can take it without disturbance to the digestion. As soon as the calves will take meal, they 
should be given bran and ground oats, or bran and some other ground meal. It may be constantly before them, but the box or vessel should be cleaned quite frequently. They may be allowed to take meal thus until they are five months old, after which the amount fed should be restricted, lest the food given should be unduly costly. They should also be given nice clean well cured fodder from the time that they will take it, and as much as they will eat of it.

Close attention should be given to the feeding. Among the attentions of much importance are the following:-

(1) Where many calves are fed simultaneously, have them take their milk from clean pans in stanchions, and when they have taken it, throw a handful of meal into each pail to remove from them, for the time at least, that propensity which they have to suck one another.

(2) Keep an ample supply of pure water accessible to them from the time that they are 2 to 4 weeks old. In hot weather this is greatly important.

(3) Give them clean comfortable and airy quarters in winter, and furnish them with ample shade in summer. 
(4) Provide for them succulent pastures including such plants as clover, good blue grass, and dwarf essex rape.

(5) Keep them in a good condition of flesh all the while, but don't allow them to become overfat.

Calves Reared for the Dairy:-Calves intended to make cows for the dairy, should always be reared by hand. The method of feeding and caring for them is just the same as that outlined above when feeding and caring for calves intended for beef, with the differences now stated. These are:

(1) It is not necessary in the case of good strong calves, to continue feeding the whole milk for a longer period than one week, before beginning the change to skim milk.

(2) It is not desirable to feed as much ground lindseed meal to dairy calves, lest they should become overfat.

(3) For a similar reason they should not be given grain food so rich as that given to beef calves. They should, however, be kept growing right along and in good flesh; whole oats, make an excellent grain ration for this class of calves.

Calves for Veal:-Calves for veal may be sold at any age that the law will allow, and onward until the age of 
several months. When sold at an age under say 6 weeks, the veal would have to be made substantially from new milk. When sold at an age beyond the time mentioned, skim milk and meal may become important factors in feeding. In such instances the feeding would be the same as that outlined for the feeding of calves for beef, with the difference that the meal fed should be stronger. Corn meal with some bran, is excellent for such feeding. Of such food, the calves should be given as much as they can stand from the first. The aim is to keep them high fleshed.

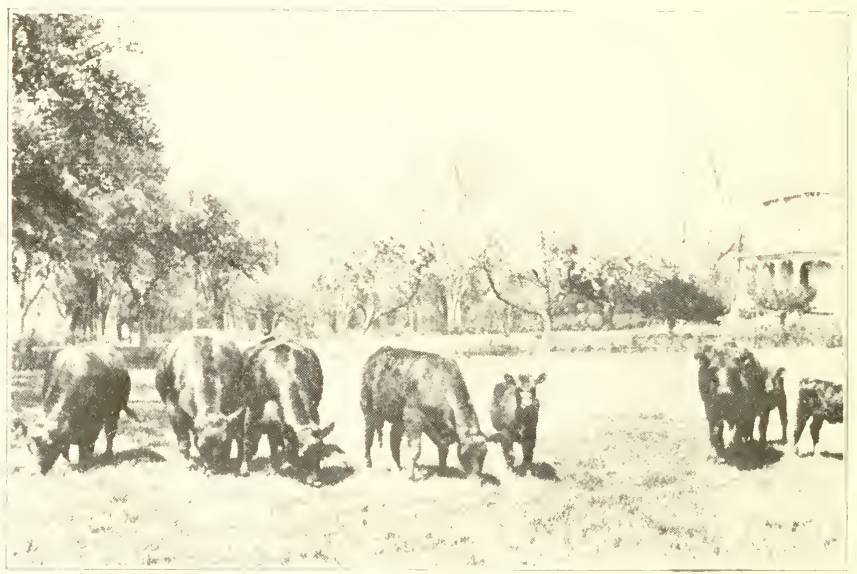

Keep the Beef Cattle Growing Continuously 


\section{The Feeding and Care of Young Cattle}

FTER the calf period, young cattle are grown for the following uses:

(1) To furnish baby beef.

(2) To furnish beef at a more mature age, and

(3) To furnish stock suitable for use in the dairy. These will now be discussed.

Cattle Grown for Baby Beef:---Cattle intended for baby beef, should be kept growing from birth until they are put upon the market, without cessation in growth for a single day. They should be kept in good condition all the while never losing what is termed the "calf flesh" which means that nice soft plump condition which characterizes the well fed calf.

The grain ration given to the calves during the milk period, should be continued, but with certain modifications until they are ready for the market. The only season when such feeding may not be necessary, is while the pastures are abundant, palatable and succulent. When the calves come in the late autumn and are turned onto good pasture in the spring, the grain ration maybe re- 
duced or even withheld for a few months, but it should be given again, if withheld for a time, as soon as the grass becomes dry. It should be materially increased the following winter, especially if the calves are to be sold in the spring at the age of 18 months. With animals thus grown, the finishing period need not last more than say three months. Before the finishing period, it will seldom be necessary to feed more than 3 to 5 pounds of meal daily, and during the finishing period, not more than 6 to 8 pounds, provided the fodder fed, is suitable in kind. During the growing period, the grain may consist of wheat, bran, oats, and corn or barley, equal parts. During the finishing period, from $1 / 2$ to $2 / 3$ of the grain ration should consist of corn, barley, speltz or rye. The grain should be ground. If the animals are to be carried to the age of 24 months, the grain ration should be moderate during the winter, withheld for a part of the summer, and renewed heavily again in the autumn.

The Fodder Fed at all Times should be of good quality. That from the legumes, as clover, alfalfa, peas and vetches is best, but fodder from corn or sorghum or the nonsaccharine sorghums is good. Corn ensil- 


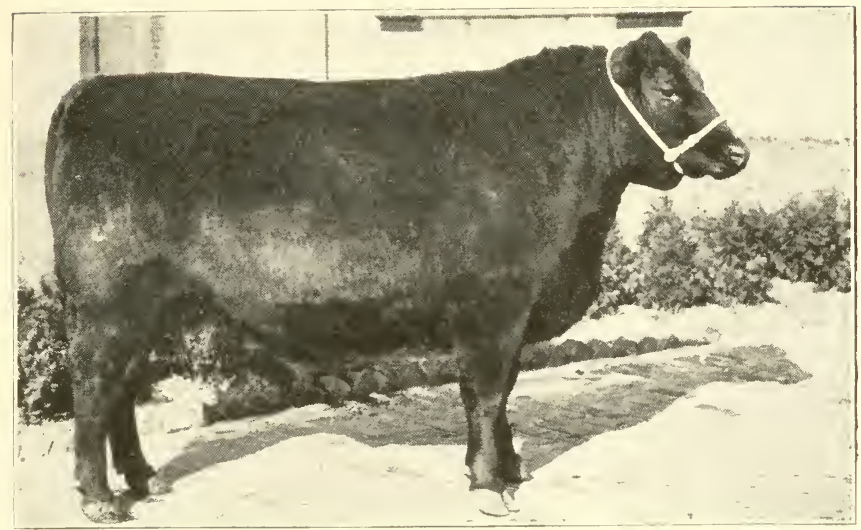

The Fat Kind-A Typical Angus Steer age is good for the feeding in winter as a part of the ration, and it furnishes cheap food. Field roots are also most excellent for developing growth in young animals. The finished animals should weigh about 1000 pounds at 18 months, and 1250 to 1300 pounds at 24 months.

\section{When Grown for More Mature Beef: When} young cattle are grown for being fattened at the age of say 3 to $3^{\mathrm{I} / 2}$ years, they too, should be kept growing in good form all the while. They should not be allowed to become thin and lean at any time. When on pasture, it will seldom be necessary to give them grain. 
Should the pasture become dry and scarce toward the approach of autum, it should be supplemented by feeding some such food as corn fodder or sorghum. In winter it doubtless pays in most instances, to feed 3 or 4 pounds of ground grain daily, especially if straw or corn stover forms a part of the ration. Such coarse fodders may be fed, but never to the extent of making the animals lose flesh. A fairly liberal supply of field roots will render unnecessary the feeding of grain, even though the fodder should consist of straw and corn stover. Ensilage will also prove quite helpful.

When Grown for the Dairy:--- When young cattle are being grown for the dairy, they should be treated much like the animals referred to above, but at no time should much grain be given to them, and at no time should they be in very high flesh, lest the system should form the habit more or less, of turning the food into fat rather than growth. On the other hand, they should not be allowed at any time to become lean, lest ultimate possible development should not be reached. If meal is fed, to any very considerable extent, it should not be made up of such carbonaceous foods as corn or rye. During the winter, field roots are excellent, for this class of stock. 


\section{The Feeding and Care of Cat- tle While Fattening}

[6] HE feeding and care of cattle while being finished, is usually done by one of three methods.

(1) Finishing on grass.

(2) Finishing in the stall, and

(3) Finishing in a shed or grove.

These will be considered separately.

Finishing on Grass:---When finished on range grasses, cattle can only be given that degree of finish that the grasses will furnish. When finished on arable pastures, these may be supplemented by soiling food or grain or by both, as occasion may require. When finished on arable pastures, so as to be turned off in the early summer months, it is necessary that they shall be given a few pounds of meal each day in the winter preceding, and that this shall be continued while they are on grass. When finished on grass in the autumn, meal is not absolutely necessary while the grass is at its best, but meal or grain in some form, will aid much in giving them a more complete finish. There is no better form in which this can be given than in the form of corn in the bundle, and 
strewn from day to day, on some clean part of the pasture.

Finishing in the Stall:---The finishing of cattle in the stall is usually done in the winter season, and it covers from 3 to 6 months of continuous feeding. Two or three weeks are called for at first in leading them up to full feeding, that is, preparing them for taking all the food that they can consume profitably. The meal should have not less than 50 per cent of bran in it, the other part being composed of some heavier kind of grain, as corn, speltz, barley, or rye, fed in the ground form. Not more than 3 to 4 pounds should be fed daily at the first, the amount being gradually increased until that quantity is reached, which is not to be exceeded. This amount should seldom go beyond say 12 pounds a day for an animal weighing 1000 to 1200 pounds. The proportion of the carbonaceous meal as corn, should increase until it forms two-thirds, if not threefourths, of the whole meal portion, the other parts being wheat, bran or ground oats; preferably the former. For 4 to 6 weeks toward the close of the finishing, the meal ration will be improved by adding to it daily, one to two pounds of oilcake. 
The fodder fed may consist of alfalfa, clover hay or clover and other hay, mixed, and fed in two feeds, the meal being also fed in two feeds. Some feeders feed three times daily, but in such feeding there is probably no advantage. Hay from the grasses only, is not so good as from the clovers. Good corn ensilage may be profitably fed to the amount of 20 to 30 pounds per day. Animals thus fed, should be allowed some exercise on mild days for a short time in a sheltered yard. The increase during the finishing period should run from $1 \frac{1}{2}$ to 2 pounds per day.

Finishing in a Shed or Grove:--In the comparatively dry climates of the west, finishing in a shed or grove or in some other sheltered place, is the method most commonly adopted, when the cattle are fed in the winter season. When so fed they should be dehorned, lest they should injure one another. They should be protected from the wind and should have a good, dry bed to lie on. The dry character of the weather makes such feeding quite practicable. The gains made are quite as good as those obtained from cattle tied in the stall, and they are obtained without calling for nearly so much labor. The food may be the same in kind 


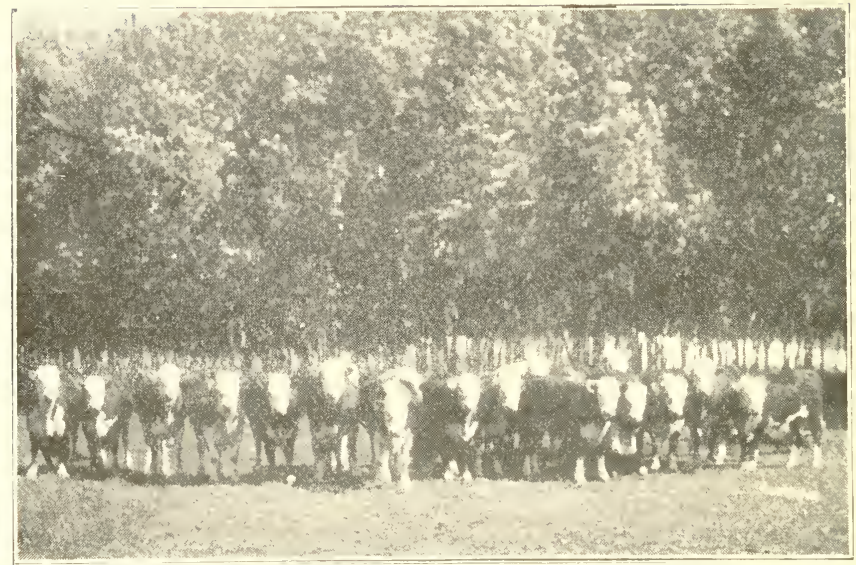

In Dry Climates Groves Make Splendid Finishin: Flaces ior Beef Cattle as that mentioned above, as suitable for cattle tied in the stall.

When thus finished, the cattle are frequently fed on shock corn, supplemented with shelled corn and a small quantity of hay. When fed shelled corn only, as the grain portion, from 20 to 25 pounds are oftentimes fed daily. Swine are allowed to gather the corn found in the droppings. While thus engaged they too are being fattened. Such feed was quite profitable years ago when corn was very cheap. It is much less profitable now because of the high price of corn. 'The animals should be well supplied with water and should have access to some form of salt at all times 


\section{The Feeding and Care of Cows When in Milk}

HE feeding and care of cows when in milk will be considered:

11) The age when they should come intc milk.

(2) Feeding and care in summer.

(3) Feeding and care in winter.

(4) The duration of the rest period, and

(5) duration of the productive period.

Age When Cows Should Begin to Milk:-The common practice is to bring heifers into milk, when they are about 24 months old, with a view to develop in them the milk giving habit at an early age. Such early milk giving however, has been found adverse to large growth in the cows, hence many dairymen do not bring their heifers into milk until they are 30 months old.

Feeding and Care in Summer:---In summer the chief requisites for dairy cows are plentiful supplies of succulent food, ample shade and a goodly supply of pure water. So long as the pastures are plentiful and succulent, no other food is wanted, although a small quantity of meal may be fed without loss and possibly with benefit, even when 
pastures are plentiful. As soon as the pastures become dry or insufficient in quantity, supplemental soiling food should be fed. Cows cannot milk freely without food being plentiful, and unless a portion of it is succulent. This food may consist of alfalfa, peas and oats, or peas and vetches grown together, millet, corn and sorghum. These are cut and fed daily and they should be fed in liberal supply. Corn ensilage makes an excellent green food, and it may be fed more conveniently than soiling food that is cut from day to day.

Shade may be furnished by trees in the pastures or near them, but the shade furnished by darkened sheds or stables is superior, especially when flies are plentiful. Running streams in the pastures, or copious springs, are ideal for furnishing water. Next to these are wells from which the water is drawn up by wind power. Cows should not be allowed to drink stagnant water from ponds or pools when possible to avoid it, as such water is much liable to taint the milk.

Feeding and Care in Winter:---When cows freshen in the fall, it is especially important that they shall be given such treatment as will result in free milk giving. This means 


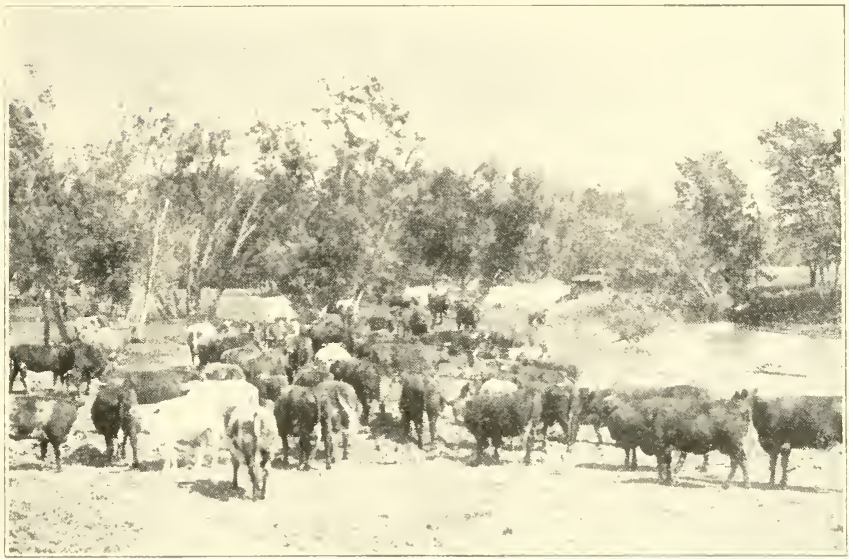

Running Streams are Ideal for Furnishing Water.

that they will be properly protected, properly fed and properly milked.

The protection or shelter for cows should be enough to keep them warm and dry. Where the winters are cold, this is usually best furnished in a stable with proper light and ventilation, but in some instances, they are kept in a shed, without being tied. When kept in stalls in stables, the plan is good which allows them to take exercise during a part of each day in a well lighted shed. The same may, or may not, be furn- 
ished with fodder, fed in racks. This is a convenient place for giving them access to water, which may be taken from a tank. In the absence of such a place for taking exercise, they may take the same in a sheltered yard, but only on fine days and for an hour or tivo at a time.

The fodder fed in winter, should be rich in protein, and fed as far as it may be practicable to secure such forage. Alfalfa and clover furnish excellent protein fodder. The same is true of pea and oat, or vetch and oat hay. When such hay can be fed, good in quality, the meal called for is much less than when other fodder, low in protein is fed, such as native or timothy hay, millet or corn fodder. The aim should be to furnish succulence in the form of ensilage or mangels. From 30 to 40 pounds of ensilage may be fed daily, or 25 to 30 pounds of mangels. Either of these classes of foods will add much to the flow of the milk.

Meal should be freely fed, if the milk production is to be maximum. With protein foods, such meal as ground corn, barley, rye or speltz, may furnish the bulk of the meal portion. When other fodders are fed, half 
the meal portion should be composed of wheat bran or wheat bran and shorts, combined. The plan is good which mixes the meal with cut fodder of some kind, when feeding it. In many instances the ensilage to be fed, is put into the feed box and the meal is thrown onto the same. The mixing is done by the cows when consuming the ensilage. "The amount to be fed will vary with certain conditions, as the nature of the fodder, and the amount of milk which the cow is producing. It is common now to feed one pound of meal daily, for each three to four pounds of milk furnished by the cow. A cow giving 24 pounds of milk daily, would therefore need 8 pounds of meal, the fodder being of average composition.

Cows should be milked with great regularity. Variation in this respect, will tend to lessen the production of milk. A record of the milk given, should be kept at the time of each milking. The milk should be tested say, three times in each month, to ascertain the amount of butter fat which it contains. In this way may be ascertained the production of each cow. The information thus obtained, makes it possible for the owner to 
improve the production from his herd, by discarding the cows that are not good producers.

Duration of the Rest Period:---In some instances cows are kept in milk for a term of years, without allowing them to go dry. The plan is not to be commended, as it taxes too much the stamina of the cow and is adverse to desirable stamina in the progeny. The rest period, that is the period during which the cow should go dry between the periods of lactation, should be not less than 6 weeks; usually this period may best occur in the autumn, while the grasses are dry.

Duration of Production:---The time during which a cow should be retained in the herd, will depend upon the continuance of her profitable production. It cannot be stated exactly in years, as cows differ much in the age to which they will continue to produce well. They do not reach maximum production until they are four or five years old. They should be able to maintain this for five or six years more; hence cows properly managed, should produce well until they are ten to twelve years old. 


\section{The Feeding and Care of the Male}

FE discussion of the feeding and care of the male will consider, (1) The food called for,

(2) The protection called for,

(3) The exercise called for.

Males should not be allowed to run with the females, first, because of the danger to life that is involved, and second, because it is not good for the males.

Food Required:-Males should be grown and maintained chiefly on protein foods. If fed mainly on carbonaceous foods during development, it will not be satisfactory. If fed chiefly on such foods subsequently, the procreative powers will be injured. The food in summer, should have succulence which may be given as soiling food. In winter, the succulence may be given as field roots or ensilage, but preferably the former. They should not be maintained in high flesh, but, on the other hand, they should not be kept lean. A small amount of meal will probably be called for, but it should not be carbonaceous. The feeding should be more free, as the service called for is exacting. 


\section{Protection Required:---In wet climates, the} male should be given the protection of a stable, but in dry climates, the protection of a shed will suffice. Trees in the paddock will give the requisite shade in summer, but not so well as the stable or shed when darkened and properly ventilated, as flies shun dark places.

\section{Exercise Required:---More or less of op-} portunity to exercise is absolutely necessary to the well being of the male. In summer this may be obtained in the paddock, to which the male should have access. In winter it may be obtained, in part at least, in a yard adjacent to the quarters in which the male is kept. In some instances exercise is secured by working the male as on tread power, or in some other way. There is merit in thus enforcing exercise. In no instances should males be kept tied in the stall. 


\section{Winter Rations}

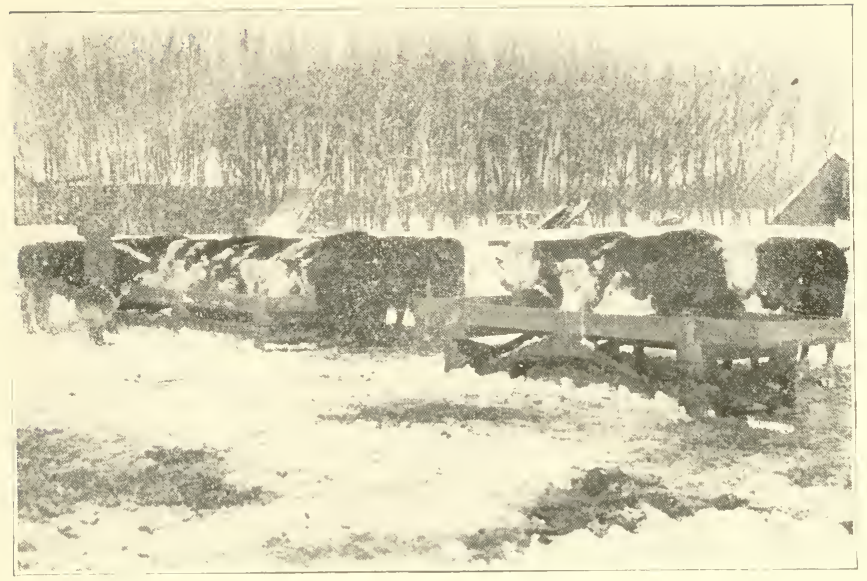

A Contented Bunch on Winter Rations

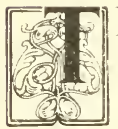

IIS is a subject that needs the careful consideration of every farmer and stockman, who would realize a profit for his pains.

In the summer, when plants and grains are plentiful, and the cattle are able to forage largely for themselves, they naturally choose those plants which their needs require. In winter however, it depends wholly upon the keeper to supply these essentials, and to pro- 
vide those elements which nature demands.

It is not sufficient that the animals have plenty to eat. They may be "eating their heads off" and still not be putting on flesh nor building bone and muscle, nor making blood to keep them warm. This is because no one article of food contains all the elements needed to build a perfect body.

All animals require a ration that contains three essential elements: Protein, carbohydrates and fat.

Protein supplies bone, muscle, hair, albumen, etc. It is very necessary to supply plenty of protein, in order to build a good frame and give it strength. Alfalfa and oil meal are especially rich in protein.

Carbohydrates supply the sugar, starch, fibre, etc. Their mission is to produce fat, or heat and energy. Naturally cattle require more carbohydrates in winter, than in summer, as more fuel is required to keep them warm. In this connection it is very essential that winter quarters be warm and comfortable; otherwise too much of the feed will be used in producing heat. 
The third element, fat, is the very best food for producing heat and laying on of fatty tissue. One pound of fat is estimated to do the work of $21 / 4$ pounds of carbohydrates. The feeds especially rich in fats and carbohydrates, are corn, timothy, barley, etc.

When you know what elements are required by your animals, you are in a position to compound a ration that will be most efficient for the animal, and economical to you. This will depend largely upon whether you are feeding for beef or for dairy purposes. Tables for all purposes may be obtained by writing to your state experiment station.

Whether cattle are being fed for beef or dairy purposes, the herd will do best if given succulent rations in combination with other feed. Cattle always do best on fresh, green pasture. The advent of the modern silo has made it possible for nearly every stockman and farmer to provide this highly relished ration for his stock, through the entire winter.

Green summer feed, stored in silos for winter feeding, is called ensilage. Usually it is made of corn, but may be other crops. The principle of the silo is the same as that of the housewife's fruit cans-the product is put into an air tight container, and preserves 


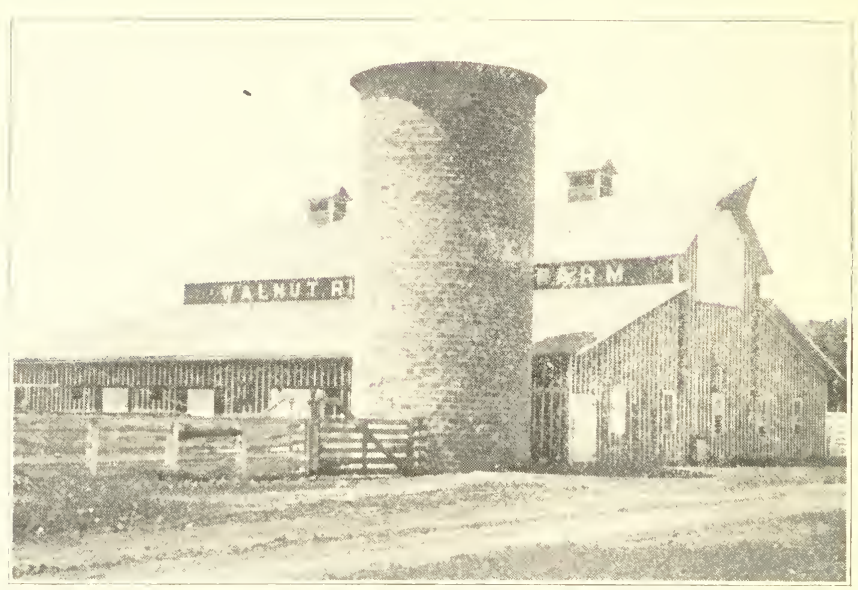

The Silo Provides Succulent Ration in Winter

its freshness and crispness until cpened for use. In addition to providing a valuable feed for winter use, it also provides against a summer drought when the pastures are burned out. It is not necessary to depend upon the weather conditions in any respect.

Because of its succulence, silage exerts a wonderful effect on the digestion of the animals; this in itself, tends to better growth and larger milk flow. It has been said that the difference between silage and the ordi- 
nary winter feed may be likened to the difference between a ripe, juicy apple and the green dried fruit. The fat and heat producing element, carbohydrates, is very pronounced in silage, and must be balanced by some feed strong in protein, to supply the proper bone and muscle element. Alfalfa is one of the best for a balancing ration and possesses the added advantage of being cheap, which makes possible the greatest economy in winter feeding. In the absence of alfalfa, bran or gluten meal may be substituted.

It is best to feed silage inside where animals can eat it without waste or without danger of the silage freezing. Never feed silage in a frozen condition. If frozen, it should be thawed out; then it becomes as nutritious and is just as greatly relished, as before freezing. If fed while frozen, it may bring on indigestion with its resultant following of lowered vitality, lessened milk flow and decreased gain in flesh. The Wisconsin Agricultural Bulletin No. 125 says "All careful stockmen heat their drinking water, but it is a much more serious matter to feed a cow 40 pounds of silage at 3"2 de- 
grees, than to give her 20 to 30 pounds of ice water.'

Careful tests have demonstrated that ten tons of silage, worth $\$ 40$, may be grown on one acre of ground, whereas the same acre will produce only two tons of hay worth $\$ 24$. This is an average of $\$ 16.00$ per acre, in favor of silage. The cost of harvesting two tons of hay, is about $\$ 3.00$, while you can harvest five tons of silage for the same amount.

Assuming that the average cow will consume five tons of silage per year, you can feed two cows an entire year, or four cows six months, from the product of one acre. It has also been demonstrated that it takes two acres to pasture one cow through six summer months. This being true, it shows that, with the silo, it is possible to maintain eight head of cows, on the same acreage required to keep one cow, without a silo.

The Missouri Farmers' Bulletin No. 11, sums up the advantage of silage as follows:

(1) Silage keeps young stock thrifty and growing all winter.

(2) It produces fat beef more cheaply than does dry feed. 
(2) It enables cows to produce milk and butter more economically.

(4) Silage is more conveniently handled than dry fodder.

(5) The Silo prevents waste of corn stalks, which contain about one-third the food value of the entire crop.

(6) There are no aggravating corn stalks in the manure when silage is fed.

(7) The silo will make palatable food of stuff that would not otherwise be eaten.

(8) It enables a larger number of animals to be maintained on a given number of acres. (9) It enables the farmer to preserve food which matures at a rainy time of the year, when drying would be next to impossible.

(10) It is the most economical method of supplying food for the stock during the hot, dry periods in summer, when the pasture is short.

The silo will be found a paying investment wherever ten cows or more, are kept. The cost of erecting a silo need not exceed $\$ 3$ per ton capacity, and may be built for less. The cost of ensilage will run, on the average farm, from $50 \mathrm{c}$ to $75 \mathrm{c}$ per ton. A good dairy cow will consume four or five tons of silage on an average per year. 


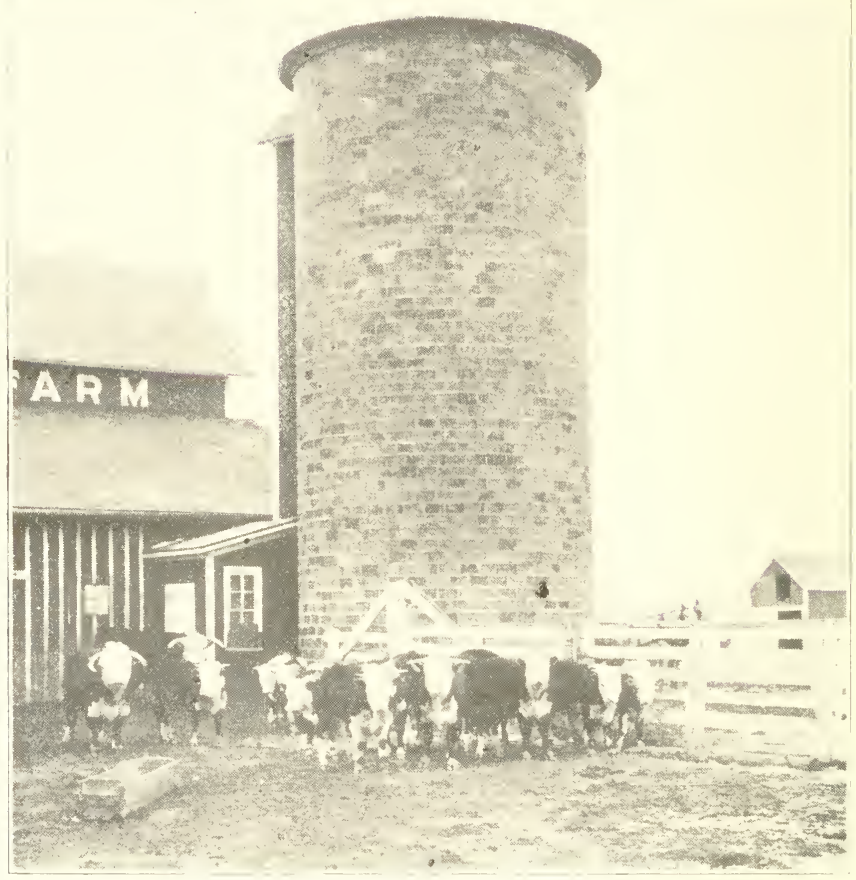

A Good Silo is One of the Best Paying Investments

For young stock reduce the average about one-third.

In feeding silage it is well to begin gradually, increasing the ration as they become used to it, until, in the case of the fully developed cattle, you are feeding about 30) pounds per day. However, the amount will depend somewhat upon the ration fed with it. 


\section{Improving the Dairy Herd}

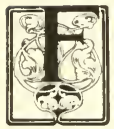

ARMERS and dairymen alike, who expect to realize the greatest profits from their herds, must weed out the non-producers and keep only such cows, as are capable of producing a heavy flow of milk and high percentage of butter fat. It will not do to rely on guess work if the greatest efficiency of the herd is desired. It often happens that when a strict test is made, it is found thattwo or three cows are consuming all the profits of the good cows. The quicker they are culled out, the better.

It is not difficult to get an exact tab on every cow in the herd. A fourteen year old boy can make the tests and give you just the information you want. The essentials are, 1 'st., a good pair of scales, (spring balance are the handiest) 2'nd., A Babcock Tester, and 3'rd., painstaking care and accuracy.

In order to determine the exact producing capacity of each cow, it is necessary to weigh her milk after each milking. A sheet of paper with a space for each cow's record every day for a month, should be tacked up by the scales. In this way the exact number 
of pounds of milk each cow produces each month may be determined.

One of the advantages of weighing the milk every day, is that, if a cow drops below her daily average, the cause may be ascertained immediately and the remedy applied before a decided loss results. If a decided drop occurs, investigation will probably show the cow has been clubbed or kicked or been run by a dog or exposed to cold drafts, or otherwise abused.

A good milker should give 6,000 pounds of milk in 300 days, or an average of 20 pounds daily. Some herds will average over 10,000. The results will depend upon the breed, and the care given. To get the best results, the feeding problem must be studied carefully, and accurate record kept. The separate ingredients should be weighed and their value determined. Only in this way can the value of any cow be determined. A careful record of this kind, may show that certain cows are not paying for their keep. Again it may show that your herd have been wasting a large percent of their feed, by sending it to the manure pile, because you have been feeding more of one certain ele- 


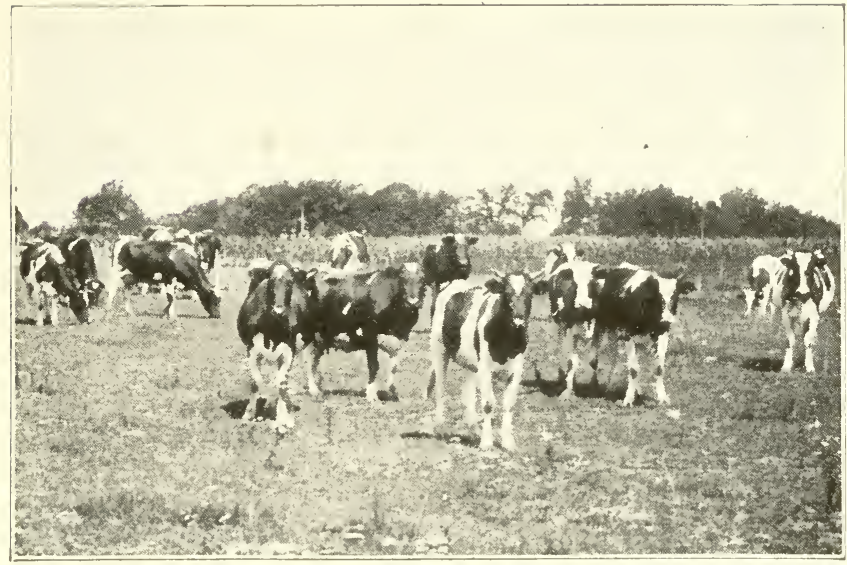

A Holstein Pasture Group

ment than they can take care of, while they are not getting enough of other elements.

In order to compound a ration for your herd, it will be advantageous for every farmer to send to the nearest experiment station to get a table of rations suited to his herd. Ordinarily a 1,100 pound cow, giving 15 pounds of milk daily, if fed on clover hay and corn fodder, will require 12 pounds of clover and 10 pounds of fodder. In addition she will require 4 pounds of corn and 1 pound of bran.

The same cow fed on ensilage, will require 
the same amount of clover and bran, but instead of grain 4 pounds of corn meal, should be given and 30 pounds of ensilage.

Whatever ration is fed, they should have daily access to "Sal-Vet" as this will enable them to digest their food properly, and keep their systems in perfect tone and condition.

A tother requirement for culling out the unprofitable members of your herd and giving you accurate information covering the profitableness of each cow, is the Babcock test. This simple little contrivance has had a wonderful influence on the dairy business, by showing up the weak members of the herds, and allowing their owners to get rid of them.

\section{Butter Fat Test.}

Before the invention of the Babcock Tester there was no way of telling just how much butter fat was contained in milk. It was known that some cows gave richer milk than others, but there was no way to determine how much more it was worth in butter producing quality.

With the coming of the creameries it became necessary to have this information be- 


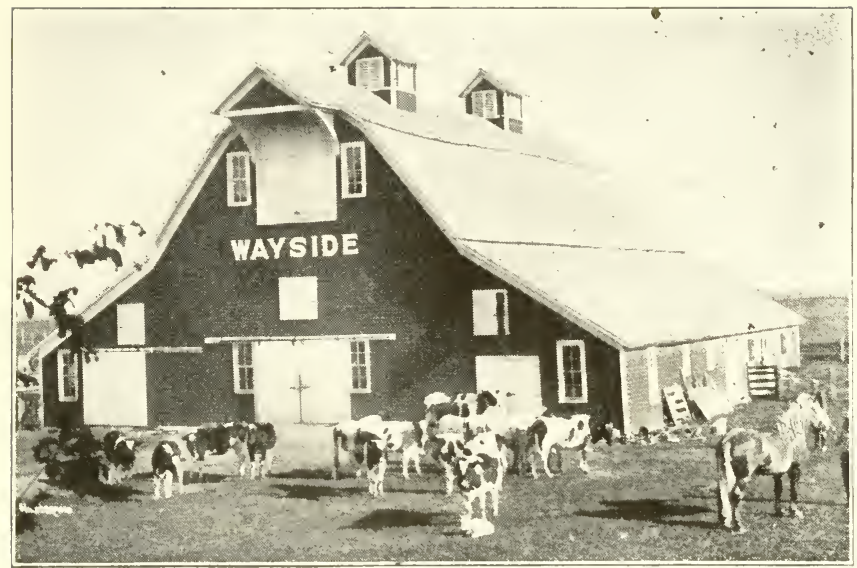

Evidence of Thrift and Contentment

cause the creamery pays according to the amount of butter fat contained in the cream. In inventing the test, Dr. Babcock made use of two well known principles. One is the fact that cream is lighter than milk which causes the milk to settle to the bottom of a vessel, while the cream rises to the top. The other is the fact that all bodies fly in a straight line, unless acted upon by some other force. Thus a revolving body has a tendency to fly away from the center around which it revolves. 
These two principles were combined in a machine holding a number of small bottles, so placed that, when the crank is turned, the bottles are whirled rapidly with the bottoms farthest from the center. The milk, being heavier than the cream, is thrown with more force and consequently farther away, which forces it all to the outside or bottom of the bottles while the cream is forced into the the neck of the bottles. Before putting the bottles into the machine, sulphuric acid is added to the milk; this breaks down the cells, and makes it easier to separate the milk and cream.

The necks of the bottles are divided into spaces indicated by marks in the glass, and by noticing the number of spaces filled by the cream, the percent of butter fat is determined. If three spaces are filled, the milk tests three percent and means that $100 \mathrm{lbs}$. of that cow's milk, contains three pounds of butter fat. If six spaces are filled, the milk tests six percent, and means that 100 pounds of that cow's milk, contains six pounds of butter fat.

How such a test sometimes turns out, is shown by one recently made in New York 
State, on a herd of 32 cows. The test showed an annual profit of $\$ 615$ for the entire herd. It also showed the startling fact that $\$ 600$ of this amount, was produced by fifteen cows, leaving only $\$ 15.00$ as the profit from the other seventeen cows. In other words, the owner was getting $\$ 40.00$ a year for milking, feeding and caring for each of his fifteen good cows, while, at the same time he was getting $88 \mathrm{c}$ a year for milking, feeding and caring for each of his seventeen poor cows.

Such information is necessary if you wish to bring your herd up to the highest point of efficiency: The low producing cows must be eliminated, and their places filled by high producing cows. A farmer selling his milk to the creamery, would not keep a three percent cow, when his other cows were producing six percent milk, unless she gave twice the number of pounds of milk. He could not afford it. It costs just as much to keep the three percent cow, often more, yet her milk brings only half as much money.

By following this plan suggested, any farmer can make his herd profit earners instead of a necessary farm nuisance, or simply a convenience. A boy who is steady and 


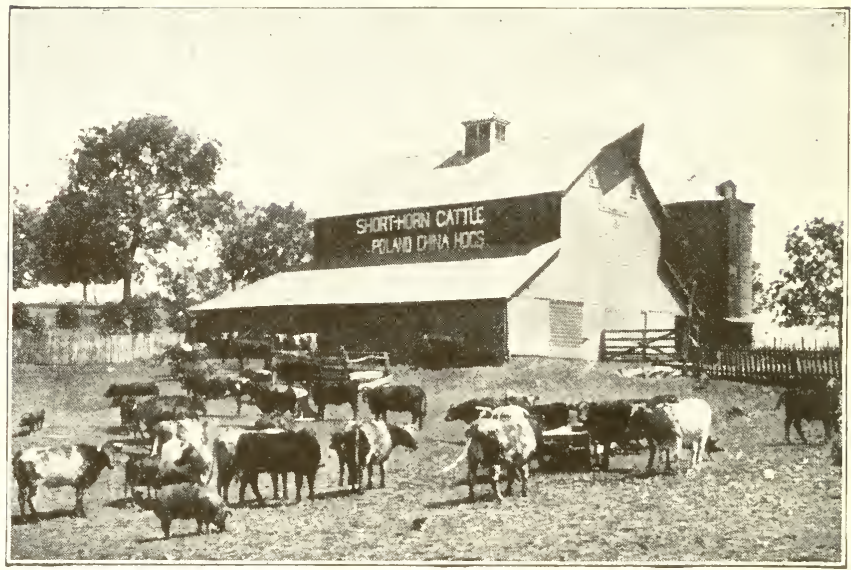

A Winning Combination-Beef and Pork

trustworthy, can earn a man's wages on the farm, by taking charge of the milkers and by careful weighing, testing and eliminating, build up the herd to a high state of proficiency. He may even find that one or more of your cows are worth a great deal more to you, than you have thought. This is the way the wonderful butter cow, Yeksa Sunbeam, was discovered. This wonderful cow was owned by a man in Minnesota who did not weigh nor test his milk, nor pay any particular attention to her feed or care. He 
did not know her worth and she was sold to $\mathrm{Mr}$. R ......... of Wisconsin. Mr.

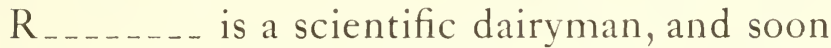
found out what a valuable animal she was. By care and proper feeding, this cow became the world's champion butter maker, producing in one year 14,920 pounds of milk and 1000 pounds of butter.

\section{Sources of Waste}

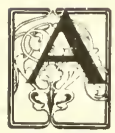

COMMON source of waste, especially on the small stock farm is the out of date method of skimming the cream from the milk. The loss of butter fat by the three most common skimming methods, water dilution, shallow pan and deep setting, is from 7 to 12 times as great as the loss from the modern centrifugal separator.

The money loss from even an average cow will amount to $\$ 10$ to $\$ 15$ annually. In addition to this there is an even greater loss in the value of the skim milk as a feeding ration. Calves and pigs fed on fresh, warm, skim milk, just as it comes from the cow and 
is separated, show a far better development of bone and muscle, than when fed on cold hand-skimmed milk. It is, in fact, one of the most valuable foods for growing animals. Also cream and butter produced by the centrifugal separator, is smoother and of more uniform quality and commands a better market price.

There are now so many good separators on the market and so many sizes, that the man who keeps even one cow, can secure a machine suited to his capacity. The in-

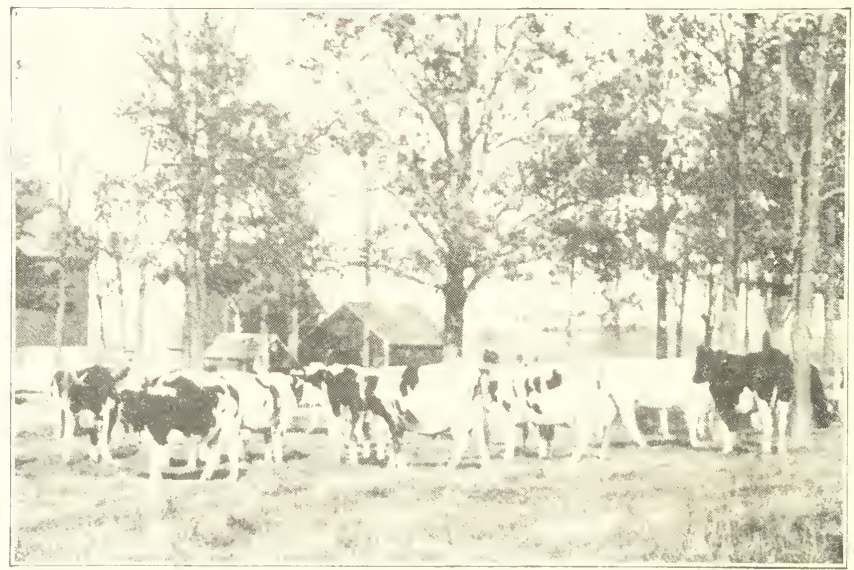

Keep Only the Best Producing Cows 
creased amount of cream which the centrifugal separator secures, will pay for a machine in a short time, and after that, will pay a good profit every day.

Whether you keep one cow or fifty cows a separator will eliminate a very prolific source of waste.

A considerable loss may result, unless care is taken in watering the stock, especially in the winter. The proper place to water stock in cold weather is the stable. If cows are turned out doors on cold, winter days, they will drink only enough to quench their immediate thirst. This is disastrous to the milk supply of the dairy cow, since water enters very largely into the production of milk. The cold water also chills the internal organs, retarding digestion and at the same time making it necessary for the animal to burn up an unusual supply of grain and feed, to regain the lost heat. Whether winter or summer, the drinking water should be cool but not cold. The farmer who pumps his water trough full of water from a deep, cold well and then turns his cattle to it from a hot sultry pasture, is inviting serious loss. The water should be allowed to stand in the sun long enough to take off the 
chill. If this is not done, the cold water will hurt their teeth and they will go away thirsty or drink any foul, stagnant water that may be accessible. In dairy cows this produces a diminished and inferior flow of milk, while in beef cattle, it brings stagnant growth, both of which mean taking dollars and cents out of the pocket of the owner. It will prove to be time and money well invested, to provide for piping or carrying water direct to the stables in winter, and for slightly warming the very cold water, in the summer.

The losses likely to result if cows are allowed to become cold and uncomfortable, is considerable. However, in endeavoring to maintain warm quarters, we must not overlook the equally important feature of pure, fresh air and sunlight. These requisites are just as necessary as warmth and water.

Many stables are so arranged that the cows stand facing each other, with feedway between them. While this is the handiest arrangement for the feeder, it is not the most sanitary, for the reason that the poisonous carbonic acid gas exhaled by one animal, is 


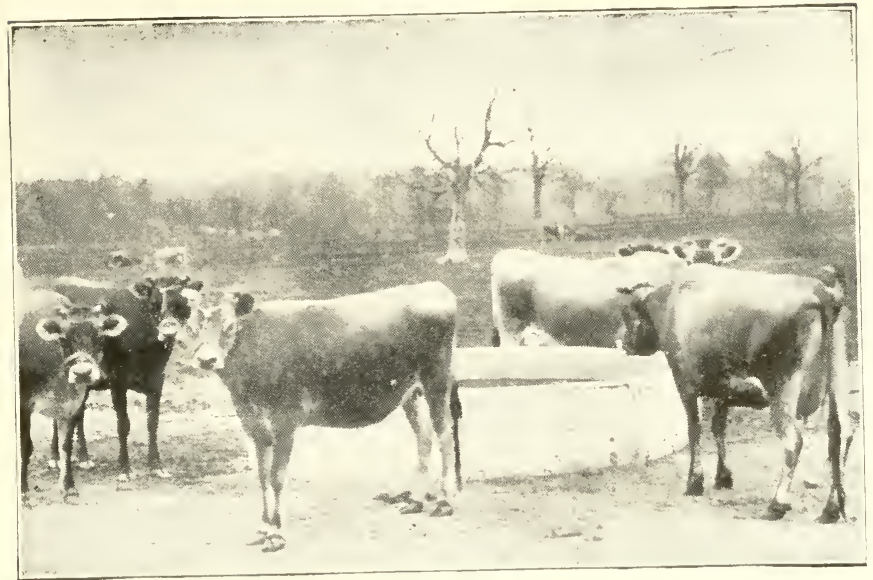

Plenty of Fresh, Pure Water Is Necessary

immediately taken into the lungs of the opposite animal. The better arrangement is to have the feeding alleys next to the outer walls. This gives the cows the advantage of pure air, and places the hind quarters of the animals, which need the most protection, nearest the center of the barn where it is warmer. A constant circulation of air should be provided by fresh air inlets, to bring in the crisp, outside air, while ventilators running from floor to roof, carry away the foul air. The walls should be tight, as open 
cracks which admit cold drafts, cause a sensitive cow to suffer greatly, and thereby decrease her milk flow. Fresh air is best admitted through windows, hinged at the bottom. By opening only part way the air is brought into the stable without causing a direct current to strike the cows.

Plenty of windows should be provided to admit sunlight to flood the interior. Sunlight is just as necessary as fresh air. If such precautionary measures as these are taken, the increased vitality of the cows will speedily show, in the increased butter and milk yield. Beef cattle and all those not being milked, and that are usually left to shift more or less for themselves, should also be provided with shelter from the cold rains and wind of winter. The small farmer or breeder who does not have stable facilities for all his stock, may provide a shelter at small expense by erecting an enclosure, open on one side only, and surrounded on top and three sides with bundles of fodder, which shut out wind and rain. Such an enclosure is warm and comfortable. It must of course be built adjoining buildings or fences, so that the stock cannot get around behind it and tear it down. 


\section{By-products}

[ege farmer or dairyman who would realize the utmost from his cattle, must not fail to take into account the by-products. In this class we may enumerate skim milk, butter-milk, smear case, whey, hides of dressed beeves and manure.

As the fertility of the farm depends upon the fertilizing elements that are put back upon it, it is obvious that the by-products are best used in such a way, as to return them to the farm soil. For this reason it is not wise to dispose of them away from the farm, unless an exceptional price is realized.

The greatest asset in the line of by-products, is the manure. It is estimated that a well fed cow will produce about ten tons, having a commercial value of $\$ 2.00$ or more, per ton. Manure is the resultant of 80 per cent of all feed given to the cow. To get the greatest value from manure, it should be treated with gypsum or some other preservative, to absorb and hold the ammonia.

Manure should be regarded as one of the most precious assets on the farm, and every precaution taken to preserve and safeguard it, that none of its value may be lost. By the 
usual methods of piling it on the ground or storing in open pens, a third to a half of its value is wasted, due to the fact that heavy rains wash away the most valuable elements, or they are burned out by "firing", due to lack of sufficient moisture. This trouble may be overcome and a superior quality of fertilizer made, by storing the manure in a concrete manure pit. This pit should be located so that it is handy to the stables, and so that the liquid manure from the stables, feeding floors and barnyard, drain into it. The floor should slope to one corner, in which should be placed a slump hole, to catch and retain the liquids. When the manure is hauled out, the liquid which is the most valuable part by 50 per cent, may be saved, by bailing or pumping it from the hole. One load of well rotted pit manure, is worth two loads, stored the ordinary way.

Next in importance among the by-products, is skim milk. It is one of the most valuable feeds for calves, pigs and all growing animals. Skim milk contains a very large per cent of protein, which is bone and muscle producing. As the important thing for growing stock is bone and muscle, and not fat, it follows that skim milk is an espec- 
ially desirable and profitable ration. By feeding the skim milk, still warm from the cow, it is in the best condition to be taken up and assimilated by the system. It is a demonstrated fact, that calves fed on skim milk, while not so fat as those fed on whole milk, attain a better bone and muscle development.

Regarding the feeding value of skim milk as a ration for growing pigs, the Arizona Agricultural Experiment Station in its Bulletin No. 43 says:

"The pigs weighed 81 pounds each when they came to the farm. They followed the steers and were fed skim milk. In 113 days they ate 6,000 pounds of skim milk, gained 248 pounds in weight and increased $\$ 16.12$ in value. With pork at $6 \% \frac{\mathrm{c}}{\mathrm{c}}$ a pound, they thus paid for their skim milk at the rate of 26.7 cents per hundred pounds.'

The value of skim milk as a growing ration for calves, is endorsed as follows, in Bulletin No. 72-Virginia Agricultural Experiment Station:

"At eight months of age, there was little difference in weight or appearance between calves developed on whole milk, and those on fresh skim milk, but the cost per pound 


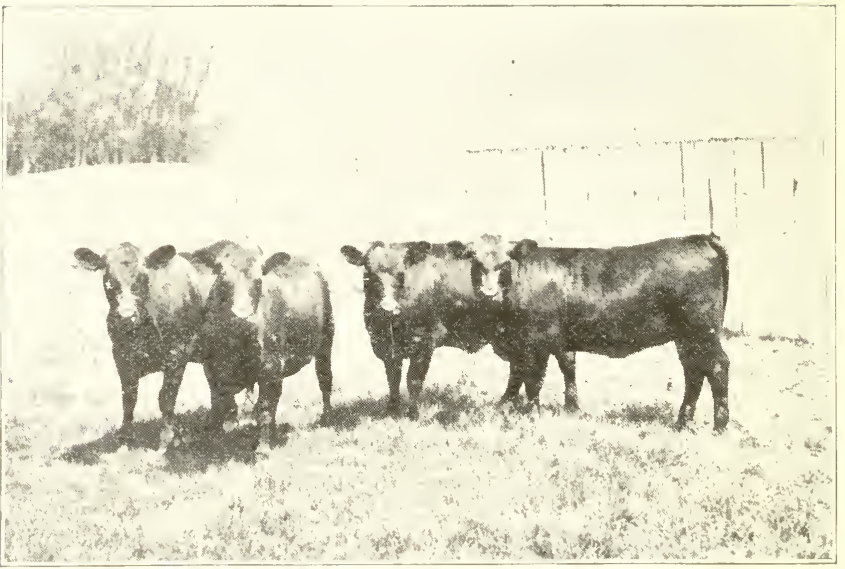

A Group of Angus Heifers

of grain for calves fed on whole milk was slightly over 10 cents as compared to 3 or 4 cents, for calves fed on fresh skim milk."

Buttermilk holds high rank as a by-product, being highly nutritious and a favorite beverage with many persons. It is in heavy demand in large city hotels, lunch counters and drug stores. It is often recommended by physicians, being especially valuable in cases of intestinal trouble. An ordinary tumbler of buttermilk contains as much nutriment, as half pint of oysters costing 20 cents. Like skim milk, the principal food ingred- 
ient is protein. This is the most expensive food element, and is the one most generally lacking in costly meals. Buttermilk supplies this deficiency in a nutritious and inexpensive form.

Cottage Cheese or smearcase is wholesome, nutritious food, and is especially relished by fowls.

Whey consists mostly of water and sugar. It is excellent for pigs, when balanced with wheat bran.

Hides properly tanned, make excellent robes. When hides are removed from calves or beeves, they should be well salted. Rub it on thoroughly and roll the hide until ready for market or for tanning.

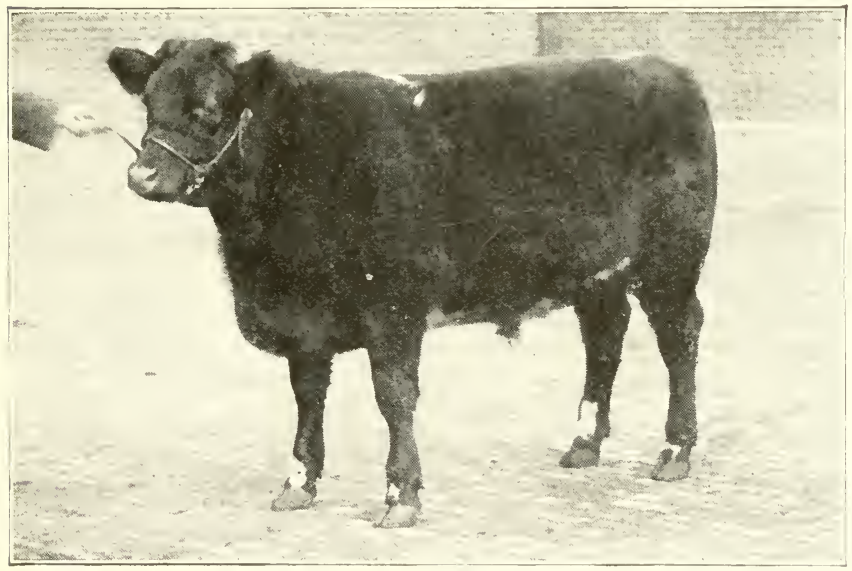

A Champion Shorthorn Steer 


\section{FACTS WORTH KNOWING}

Don't run the milk cows, if you expect them to yield you a profit.

Bloody or stringy milk may be overcome by feeding nutritious food and giving "Sal-Vet" daily.

Clover hay and good yellow carrots will give the right color to your butter.

Leaky teats should be treated only when the cow is "dry." Cauterize the opening with caustic potash or a hot knitting needle.

Blue milk is an indication of impoverished blood. Feed "Sal-Vet" to overcome this condition.

Cows with depraved appetites will lick boards, eat dirt and straw manure, which taint the butter. Give wholesome feed and "Sal-Vet" to overcome the tendency.

Many a good cow has been ruined as a milker, by blows on the udder, from stones or clubs. Teach the boys not to throw at the cows.

Never attempt to drench cattle. When their heads are in position for drenching, they cannot swallow and the drench is very liable to go into the lungs, causing more serious trouble than the one it was intended to cure.

The first milk of a cow after calving, is rich in albumen and salts. This is to purge the bowels of the calf of a tenacious sticky yellow matter, which must be removed before nature will perform her functions properly. See to it that the calf gets this first milk, otherwise the calf will probably be costive and may have considerable trouble.

Indigestion is the cause of 90 percent of the ills of all farm animals. Guard against it as you would a plague. There is no better nor more effective way of doing this, than keeping "SalVet," where your animals can have free access to it every day. It will put their digestion in good order, tone the system, and keep your animals in condition.

Lead poisoning often results from cattle licking newly painted barns and in that way swallowing a quantity of white lead. They seem to have a mania for licking paint. Keep them away from it, Do not throw empty paint cans into the pasture where they can get at them, neither should you paint a silo inside, immediately before filling. 


\section{DISEASES OF CATTLE}

While cattle are not so apt to develop intestinal diseases as hogs and sheep, worms often attack them, and retard thrift. This condition affects your profits probably as much as in the case of other stock. A bull out of condition makes him undesirable for use on your herd. Steers that are infected, will not fatten readily. The milk yield from the dairy cow is decidedly decreased by this condition.

Indigestion and disordered liver are the most common ailments affecting cattle.

The skin in its feeling and appearance, is an important guide to the condition of cattle.

A dry, lusterless appearance, and what is called "hidebound," are symptoms of poor nutrition, arising from indigestion, improper food, and worms. dition.

The "staring coat" indicates debility or lack of good con-

When cattle lose their cud-that is, cease to ruminate without apparent cause, there is some interference with the digestive process. No animal can thrive in this condition.

Owing to the abnormal demand made upon them, milch cows are most liable to get out of condition.

The dairy cow is expected not only to be maintained in good condition, but also to give the needed nourishment to her unborn calf.

The period of lactation has been extended for a period longer than is naturally required of the cow for the sustenance of her calf, and often there is no let-up in the demands upon her between the birth of one calf and the next.

It is for this reason that cows have a tendency to tubercular trouble.

When the digestion has become impaired, or the liver disordered, the milk glands are called upon to assist in eliminating the poisonous matter from the blood. This infects the milk and reduces the yield as well.

By giving "Sal-Vet" tone and health are imparted to the digestive organs and the milk secreting glands, and so the normal yield from what you feed, will be obtained.

It is only by keeping cows in this state of good condition that they are enabled to produce the greatest amount of milk from their feed. 


\section{Abortion.}

Abortion is one of the most troublesome maladies with which cattle raisers have to contend. It is most commonly due to contagion, altho' it may result from a number of other causes, such as blows and kicks from vicious keepers, being horned by other caitle, falling, slipping or straining, internal chilling from ice water. over-feeding, giving spoiled rations, or sudden change of diet. These latter causes may all be avoided by careful owners, but contagion is not so easily handled.

Contagious aborticn is a germ disease, which may be communicated to an entire herd, or even to all the cattle in the neighborhood. The loss through this one disease in a single year is enormous and may be conservatively estimated at $\$ 130,000,000$ to $\$ 150,000,000$ annually.

\section{The Symptoms of Abortion.}

If more than one cow out of a herd meets with abortion, it is cause for suspicion and should be thoroughly investigated, and a careful watch put on the entire herd. Usually an afflicted cow will show a swelling of the vulva, and there is a disposition not to mix with the rest of the herd. She will cease to chew her cud and becomes restless on her feet.

The first unmistakable symptoms are the presence of small red spots on the lining of the membrane of the vulva. This is an infallible sign; any cow so afflicted, is in condition to spread the contagion to the entire herd.

\section{How to Eradicate the Disease.}

It is not sufficient to isclate the afflicted cow, or to treat her separately, in order to stamp out the disease. Nothing but the most thorough measures with the entire herd and also with their living quarters, will suffice. Calves dropped by affected cows, will certainly bear the germs in their blood, and as they generally have scours, their excrement is a fruitful source of infection.

The most dangerous and fruitful source of contagion, is the bull. After he has served an affiicted cow, he wiil carry the germs to all the cows of the herd or neighbors' herds.

The genital organs of both cow and bull should receive a thorough syringing with a solution of water and a reliable disinfectant, using one ounce of the latter to a gallon of water. Clip the hair from the sheath of the bull and from the cow's tail, from switch to back bone. Disinfect the stables thoroughly, not 
forgetting the calves' stalls. Make a thorough job of it. Sweep down the walls, scrub the floors with hot water and washing soda. Apply carbolic acid and water in the proportion of 1 to E0, to all exposed surfaces. Remove earth floors to a depth of three inches and substitute cement or new earth. Whitewash the quarters thoroughly, and admit all the sunlight possible.

Afterbirth must be removed immediately, and burned or deeply buried.

$\mathrm{B}$ 1ild for vigor and pure, rich blood by feeding the herd "Sal-Vet". Keep it where the animals can have access to it at all times, It will rid them of stomach and intestinal worms, enable them to get the full benefit of their feed, and put the herd in condition to better withstand contagion.

"Since feeding SAL-VET for a couple of years to my cows, there has not been a case of abortion among them. I also tind it the best tonic I can get for young pigs."

C. N. McCauley, Darrowville, Ohio.

\section{Anthrax.}

Anthrax is a dangerous germ disease. It is primarily a disease of cattle, but may be communicated to other animals; even man may contract it as a result of skinning an animal, that has die $\perp$ of the disease.

Cattle afflicted with Anthrax usually develop a fever of 106 or 107 degrees. They manifest great weakness, their jaws champ, limbs tremble and violent chills are developed. The horns and ears become cold, the nostrils distend and they breath hard and with open mouth. The mucous membranes of the nose and mouth become blue, and in the last stages of the disease, blood oozes from nose, mouth and bowels.

All animals that are hopelessly sick should be killed. Cover with quicklime and bury deep. Disinfect the premises thoroughly with carbolic solution. Mix twelve ounces each of carbolic acid and sodium bicarbonate, with four fluid ounces of glycerine. Give a tablespoonful of this preparation in a quart of water, morning, noon and night to all suspected animals.

Place 'Sal-Vet' where all animals can run to it at will. The 'Sal-Vet' acts as a stimulant, tonic and blood purifier, and will put the herd in condition to better resist the disease.

\section{Barrenness.}

This condition arises from diseased, imperfect, or unnatural reproductive organs. The causes which lead to barrenness may 
be transmitted, and for that reason, this condition in a herd should be carefully investigated. A retention of the afterbirth, becoming decomposed, may produce a catarrhal condition and cause barrenness. A cow afflicted with a catarrhal discharge, if bred to a perfectly healthy bull, may be the means of spreading the infection through an entire herd.

Before breeding, a cow should be carefully observed and should be brought into the highest state of vigor and hardiness by daily feeding of 'Sal-Vet.' If unnatural discharges are apparent, such as a red or chocolate discharge with a sweetish, sickening odor, she should not be allowed to breed. The most essential thing is to build up the constitution, enrich the blood and put the cow into a state to resist and overcome the disease. This may best be done by allowing free access to 'Sal-Vet'. It strengthens every part, enriches the blood, improves the digestion when faulty and puts the animal in fine physical condition.

\section{Tympanites, Hoven or Bloating.}

Bloating is the result of fermentation of gas in the paunch. The condition is due primarily to indigestion. This may result from a too greedy eating of young clover, especially if wet or frosty. Any food eaten too hastily, or when too cold or too wet, is liable to disarrange the digestive processes and set up a fermentation, causing bloat.

The symptoms of bloat are a drum-like swelling on the left side immediately in front of the hip. The animal moves uneasily and gives every indication of distress. The trouble usually comes on quite suddenly and unless relieved, the stomach becomes enormously distended and suffocation may ensue. In severe cases, death may result in from 10 to 30 minutes.

Unless the case is too far advanced, the most simple remedy is to exercise the animal. A brisk run of half a mile will usually effect a recovery. In urgent cases, puncture the paunch immediately with tractor and canula. This is a sharp blade in a tube about half an inch in diameter and eight inches long. When the puncture is made, the tube remains in the opening, allowing the gases to escape, and giving instant relief. This instrument should be a last resort only, and should be used only under the direction of a veterinarian. 


\section{DISEASES OF CATTLE}

If the animal is not greatly distressed and exercising fails to produce results, give two ounces of aromatic spirits of ammonia in one quart of cold water every half hour, or one-fourth ounce of chloride of lime in 1 pint of warm water, every half hour.

To prevent recurrence feed 'Sal-Vet' daily. Keep it where the entire herd can run to it whenever they want it. It helps because it absorbs the noxious gases in the stomach. Besides, it tones the entire system and keeps the digestion good.

\section{Diarrhoea.}

This trouble occurs in all seasons of the year, and may be an indication of indigestion. The causes that lead to it are many. It may be overeating, especially of soft, watery feed, drinking strange or impure water, excess of bile, bowel inflammation, exposure to decided change of temperature, or it may be a symptom of some other disease lurking in the system.

In any case, diarrhoea is an indication that nature is trying to eliminate from the system, matter which should not be present, and it is well to assist nature by giving a milk purgative. A pint of castor oil is excellent. Also give a little ground feed night and morning, until the excretions are normal.

Diarrhoea being a disorder of the digestive organs, it may often be avoided, by allowing the cattle to have 'Sal-Vet' daily. Place it where they can have free access to it at all times.

\section{Milk Fever.}

This is a common and frequently fatal disease, which attacks cows immediately following calfbirth; usually after third to sixth calf. It is known by several different names, depending upcn the locality. Some of these names are: Calving Fever, Parturition Fever, Parturient Apoplexy, Parturient Collapse and Puerperal Fever.

The symptoms are so pronounced as to be recognized by the most inexperienced. The first indications are restless, excited actions, occasional bellowing and symptoms of colic. Within a few hours paralysis begins. It is indicated by loss of control of the hind legs, weakening of the knees and later by complete collapse and unconsciousness. The head is thrown to one side, 
neck arched. The throat becomes more or less paralyzed. Great care must be used in giving liquid medicine through the mouth, because the fluid is very liable to enter the lungs through the larynx, and cause tratimatic pneumcnia, which is fatal in nearly all cases. Prop the animal on her breast with bundles of straw and keep her covered with blankets.

The best and simplest treatment is an injection of air into the udc'er, by means of a milk fever instrument. Either recovery or death results within eighteen to twenty-four hours, but lcsses are comparatively few in cases in which the air treatment is given.

Prevention is the easiest course and this is best done by allowing plenty of exercise and feeding laxative focd before calving. It is very important that the digestion and elimination be perfect and to insure this, keep 'Sal-Vet' constantly before the cow. Avoid excessive fattening. In susceptible cows, allow the milk to remain in the udder, except what the calf requires, and this should be drawn from all four quarters.

\section{Constipation.}

Constipation is not regarded as a disease, but rather as the symptom of a disease. At the same time it is one of the most common ailments, and is a frequent cause of death. This is because a very large percentage of the cases of constipation is due to bowel paralysis. In order to cvercome constipation, it is necessary to remedy the conditions which lead to constipation. Overfeeding and indigestion are probably the most common causes of constipation and in these cases, 'Sal-Vet' will be found the best regulator.

Calves are frequently troubled with constipation at birth, because of a faulty digestion in the mother. To avoid this see that 'Sal-Vet' is placed where she can have free access to it at all times. "Sal-Vet" supplies the required essentials to keep the system properly toned, and the digestion and elimination as they should be.

\section{Colic or Cramp.}

This is an ailment of the digestive organs and usually results from eating indigestible food or drinking cold water. The symptoms are uneasiness, drawing up the hind legs and lying down and immediately getting up. 


\section{DISEASES OF CATTLE}

Exercise the animal ten minutes. If this does not start a bowel movement, give one ounce sulphuric ether and c ne ounce tincture of opium in one pint of water. Repeat the dose in half hour if not relieved.

Trouble arising from indigestion is best avoided by keeping "Sal-Vet"' before the animals at all times.

\section{Caked Udder (Garget)}

Caked Udder or Garget is a very common ailment, usually due to the condition of the blood. It is also caused by careless milkers leaving a quantity of milk in the udder and its presence is usually manifested by inflammation, fever, sweiling and hardening of the afflicted part.

Poultices should be applied, and the animal deeply bedded to prevent any dampness of the udder. If the trouble becomes infectious, care must be taken not to communicate it to others. The hands should be washed thoroughly in an antiseptic solution before attempting to milk cows. Disinfect the stables thoroughly.

Inflate udder three to six times daily, using a small bicycle pump and milk tube.

"SAL-VET" is a fine thing. It was well worth the price for my cows alone. I have Holstein and some of them have had trouble with their bags becoming caked. This spring they were free from it, with a single exception, and I attribute their improvement to " $\mathrm{SAL}$ " VET."

Ernest F. Daisher, Britton, Mich.

\section{Calf Cholera (Scours)}

Calf Cholera is the virulent form of scours, due to failure of the calf to properly digest its food. Indigestion itself may be due to a number of causes, chief of which are feeding of milk to a very young calf, taken from a cow long after calving; allowing the calf to suck the first milk of a cow that has been driven, shipped or otherwise violently excited; allowing the calf to wait too long between feeds; feeding milk that has stood in an unscalded pail; keeping calves in close, dark, damp or iil-smelling pens. All of these things should be carefully watched and the calf given milk from "Sal-Vet" fed cows only. If the mother 
has only moderate access to "Sal-Vet" before the birth of the calf, the latter will have an inheritance of vigor and good digestion.

Ordinarily, in its early stage, scours is not contagious, but if indigestion is not overcome, fermentation in the indigested masses becomes more active, germ propagation sets in, and the disease becomes infectious.

When it is discovered that a calf has scours, it should be placed in a warm, lighted stall and given a mild laxative and fed regularly---not too much at one time.

Prevention is easier than a cure; care of the mother is a long step in the right direction. Be sure that she receives all the "Sal-Vet" she wants as this is the way to prevent scours or indigestion in her offspring. As soon as the calf is a few days old place a little "Sal-Vet" before it; it will keep its digestion in proper order, without further aid.

\section{Hard Milkers}

A cow that is a hard milker is of little value, compared to one that milks easily. This is not because she is deficient in quantity or quality of milk, but because no one wishes to use or purchase a hard milking cow.

In order to treat this condition, it is necessary to know what causes it. It is due to a paralysis or contraction of the sphincter muscles at the point of teat. Treatment consists of a dilating the muscles until the flow of milk passes out readily.

Procure a teat dilator, apply a small quantity of vaseline and insert dilator into the teat far enough to admit the bulb. This stretches the muscles and their contraction below the bulb holds the dilator in place. Retain the dilator in the teat from one milking to the next, until milking is made easy. Usually this will require less than one week.

D) not use milking tube in place of dilator, as infection may result from the admittance of air.

\section{Tuberculosis}

Tuberculosis is one of the most dreaded diseases because of its insidious nature, resistance to treatment and the danger of contagion. The tubercle baccilli may be present in the cow for months, or even years, without knowledge of the owner and be a constant menace, not only to the other animals, but also to the owner and his family, according to some authorities. The 
safe way is to apply the tuberculin test at least once a year, and oftener, if the disease is present in the herd.

No cure has ever been found for tuberculosis. For this reason it is very essential to prevent its appearance in the herd. To do this, animals must be kept in a hardy well nourished condition. Cattle that are low in health and vitality are especially liable to contagion. We cannot too strongly recommend "SalVet' as a preventive, as it is the greatest tonic, invigorator and builder obtainable. It will not cure the disease, but-its constant use will lessen the danger of contracting it, because by strengthening the digestive and assimilative functions, it increases the animals' power of resistance.

It must be remembered, too, that tuberculosis is an indoor disease. Fresh air and sunshine are the two agents that spell death to the tuberculosis germs. See that plenty of both are admitted to the stables, and that the quarters are kept clean.

The symptoms most peculiar to tuberculosis are an unnourished condition of body, in spite of abundant feed, dull short cough, especially noticeakle in the morning, after drinking, sunken eyes, lusterless coat. The disease is so insidious, however, that it may bc present for many months before the symptoms become apparent, and it may be necessary to apply the tuberculin test to tell whether the disease is present. If so, it will be indicated by a rise in temperature, following the injection. Some states conduct this test without cost to the owner, and diseased cattle are condemned to death, and the quarters are then thoroughly disinfected.

\section{WHAT USERS SAY}

\section{From the Treasurer Holstein-Friesian Breeders's Ass'n of Illinois}

"Will say that we like your "Sal-Vet" fine. It is just the thing to keep stock in fine thrifty condition. This has been our experience with it."

A. H. Nokes. Springfield, Ill.

"I had a Jersev cow that would not eat a thing, and became so poor that she was unable to get up without help. I had triesl all kinds of medicine, but nothing helped, and she steadily grew worse. Then the "Sal-Vet" arrived, but she was so weak that I had to give it to her with a spoon. It fixed her up in a short time. She is now in splendid condition. "Sal-Vet" has also been the means of putting the rest of $\mathrm{my}$ stock in fine condition.

C. R. Gano, Mascotte, Fla. 


\section{State Agricultural Experiment Stations and Colleges Endorse}

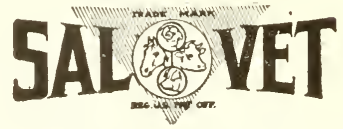

\section{From Ohio State University; College of Agriculture.}

"We have used 'Sal-Vet' with excellent satisfaction, and while we have not obtained information as to the absolute effect on our sheep, they consumed the preparation with results which appear to us to corroborate your statement, that it is desirable for discouraging the development of worms, and keeping sheep in a good condition.

'I believe that 'Sal-Vet' will repay the user, in the results which come from its action in his flock."

C. S. Plumb, B. Sc., Prof. of Animal Husbandry.

\section{From Oklahoma Experiment Station.}

"Please send us another shipment of 'Sal-Vet.' We endeavor to keep a constant supply of 'Sal-Vet' before our sheep, particularly at this time of the year when there is greatest danger of lambs and sheep contracting stomach worms and other parasitic diseases.'

W. A. Linklater,

Animal Husbandman.

\section{From California College of Agriculture.}

"We received the 'Sal-Vet' some time ago and are feeding it to our breeding sheep. It is doing the work in fine shape."

J. J. Thompson, Dept. Animal Husbandry.

\section{From North Carolina College of Agriculture.}

"In my live stock work here in North Carolina I have had an opportunity to recommend your 'Sal-Vet' to a number of stockmen. Having used it at New Hampshire College last year and year before, I am in a position to know its great value. Our cattle have done well ever since we began using 'Sal-Vet,' and I am always glad to recommend an article that is as good as the one you are placing on the market.',

John C. McNutt, Prof. Dept. Animal Husbandry. 


\section{Additional Experiment Station Endorsements}

\section{From Iowa State College}

'We have been using 'Sal-Vet' now for two years, and to tell the truth are somewhat surprised at the good results we have secured with it. Our lambs have been quite free from parasitic trouble. We have been using 'Sal-Vet' quite faithfully during these two years, and believe it is a vermifuge of considerable merit. We lost one lamb late last summer, and upon posting it, found a few stomach worms, but not enough to kill the lamb. In all, we have posted two lambs out of the bunch which have been receiving 'Sal-Vet', and found stomach worms in both cases. However, these stomach worms were not present in large enough numbers to cause serious injury to the sheep.

We know that our pastures are infected with stomach worms, and feel that 'Sal-Vet' has been responsible in keeping the loss from this source at a minimum. We wish to carry on the experiments with 'Sal-Vet' more thoroughly.

(Signed)

John M. Evvard,

Assistant Chief in Animal Husbandry, Iowa State College and Exp. Sta., Ames, Iowa.

\section{From Connecticut Agricultural College.}

"We have used 'Sal-Vet' with good effect on our sheep. Our lambs have never done so well as this spring."

L. A. Clinton, Director.

\section{From North Carolina Experiment Station.}

"We find 'Sal-Vet' a very satisfactory worm exterminator, and are very much pleased with results."

R. S. Curtis, Animal Husbandman.

\section{From Nashville Agricultural and Normal Institute, Madison, Tenn.}

"After making a number of interesting tests on our sheep, I am confident that 'Sal-Vet' will destroy worms."

E. A. Sutherland, President.

From South-East Alabama Experiment Station, Abbeville, Ala. “' 'Sal-Vet' has been of great service to us. It has kept our hogs and pigs free from worms, and furthermore, has demonstrated that it is a splendid tonic."

J. Buhrmas Espy, Agriculturist. 


\section{CONTENTS}

Preface Page

Cattle Breeding,-

Selecting Beef Cattle,-

Selecting Dairy Cattle, -

Selecting Cattle of Dual Type,_-Prof. Thos. Shaw __Pages 12-13

Breed of Cattle,-

Prof. Thos. Shaw__Pages 13-25

Dual Breeds

Pages 14-15

Dairy Breeds Pages $16-20$

Beef Breeds. Pages 21-25

Feeding Cattle,-

Management,-

Feeding and Care of Calves,_- Prof. Thos. Shaw __ Pages 33-40 Feeding and Care of Young Cattle,_- Prof. Shaw_._Pages 41-44 Feeding and Care of Cattle While Fattening, -

Prof- Thos. Shaw _. Pages 45-48

Feeding and Care of Cows in Milk, - Prof. Shaw__Pages 49-54 Feeding and Care of the Male,_-Prof. Thos. Shaw _ Pages 55-56 Winter Rations Pages 57-64

Improving the Dairy Herd Pages 65-73 Simple Test for Butter Fat 68 Sources of Waste Pages 73-78 By-Products Pages $79-83$

Facts Worth Knowing Page 84

Diseases of Cattle. Pages 85-93

What a Number of Experiment Stations Say about Sal-Vet Pages 94-95 

MAY $12 \quad 19: 3$ 

LIBRARY OF CONGRESS

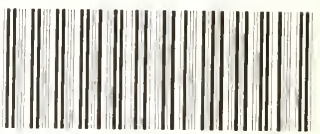

00028194225

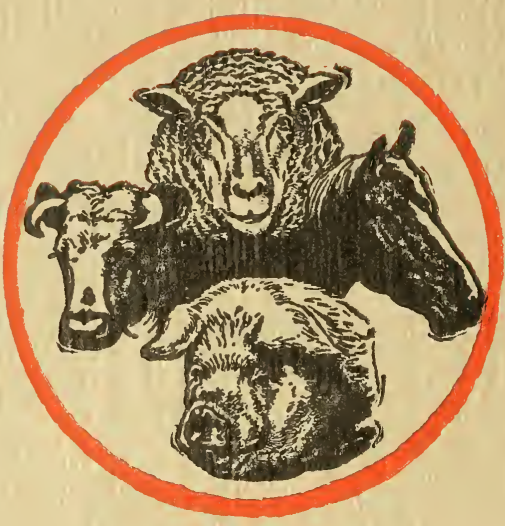

